\title{
IgM Immunoglobulin Influences Recovery after Cervical Spinal Cord Injury by Modulating the IgG Autoantibody Response
}

\author{
(D)Antigona Ulndreaj, ${ }^{1,2}$ Pia M. Vidal,, ${ }^{1,5}$ Nicole Forgione, ${ }^{1}$ (D) James Hong,, ${ }^{1,2}$ and \\ (1) Michael G. Fehlings $1,2,3,4$
}

https://doi.org/10.1523/ENEURO.0491-19.2021

${ }^{1}$ Division of Genetics and Development, Krembil Brain Institute, University Health Network, Toronto, Ontario M5T 2S8, Canada, ${ }^{2}$ Institute of Medical Science, Faculty of Medicine, University of Toronto, Toronto, Ontario M5T 2S8, Canada, ${ }^{3}$ Department of Surgery, Faculty of Medicine, University of Toronto, Toronto, Ontario M5T 2S8, Canada, ${ }^{4}$ University of Toronto Spine Program, University of Toronto, Toronto, Ontario M5T 2S8, Canada, and ${ }^{5}$ Department of Basic Science, Biomedical Science Research lab, Faculty of Medicine, Universidad Católica de la Santísima Concepción,

Concepción, Chile 4090541

\begin{abstract}
Spinal cord injury (SCl) results in the development of detrimental autoantibodies against the lesioned spinal cord. IgM immunoglobulin maintains homeostasis against IgG-autoantibody responses, but its effect on $\mathrm{SCl}$ recovery remains unknown. In the present study we investigated the role of IgM immunoglobulin in influencing recovery after $\mathrm{SCl}$. To this end, we induced cervical $\mathrm{SCl}$ at the $\mathrm{C} 6 / \mathrm{C} 7$ level in mice that lacked secreted lgM immunoglobulin [IgMknock-out (KO)] and their wild-type (WT) littermate controls. Overall, the absence of secretory lgM resulted in worse outcomes as compared with WT mice with SCl. At two weeks after injury, IgM-KO mice had significantly more lgG antibodies, which fixed the complement system, in the injured spinal cord parenchyma. In addition to these findings, IgM-KO mice had more parenchymal T-lymphocytes as well as CD11b+ microglia/macrophages, which co-localized with myelin. At 10 weeks after injury, IgM-KO mice showed significant impairment in neurobehavioral recovery, such as deteriorated coordination, reduced hindlimb swing speed and print area. These neurobehavioral detriments were coupled with increased lesional tissue and myelin loss. Taken together, this study provides the first evidence for the importance of IgM immunoglobulin in modulating recovery after $\mathrm{SCl}$ and suggests that modulating $\operatorname{lgM}$ could be a novel therapeutic approach to enhance recovery after SCl.
\end{abstract}

Key words: functional recovery; IgG-autoantibody response; IgM immunoglobulin; spinal cord injury

\section{Significance Statement}

The present study provides novel evidence for the protective role of IgM immunoglobulin in SCl. Using a clinically relevant mouse model of $\mathrm{SCl}$ at the cervical level $(\mathrm{C} 6 / \mathrm{C} 7)$, we show that deficiency of IgM immunoglobulin results in impaired neurobehavioral recovery, coupled with increased lesion size, less white matter sparing, and enhanced deposition of complement-fixing IgG antibodies in the spinal cord. These data provide evidence for the necessary role of IgM immunoglobulin in spontaneous recovery during cervical $\mathrm{SCl}$ and warrant more research into the therapeutic effect of IgM administration after SCl.

\footnotetext{
Received November 25, 2019; accepted June 10, 2021; First published August 19, 2021.

The authors declare no competing financial interests.
}

Author contributions: A.U. and M.G.F. designed research; A.U., P.M.V., N.F., and J.H. performed research; M.G.F. contributed unpublished reagents/ analytic tools; A.U., P.M.V., N.F., J.H., and M.G.F. analyzed data; A.U. and M. G.F. wrote the paper. 


\section{Introduction}

There is compelling preclinical and clinical evidence that spinal cord injury (SCl) results in the development of autoantibodies against spinal cord tissue as well as the induction of systemic autoantibodies (Mizrachi et al., 1983; Petrova et al., 1993; Hayes et al., 2002; Ankeny et al., 2006, 2009; Davies et al., 2007; Zajarías-Fainsod et al., 2012; Ulndreaj et al., 2017; Hergenroeder et al., 2018). Although the role of autoantibodies in human $\mathrm{SCl}$ remains largely unknown, research in animal models indicates that autoantibodies have a detrimental effect post-SCI (Ankeny et al., 2006, 2009). Thus, understanding the mechanisms that lead to the development of autoantibodies after $\mathrm{SCl}$ and limiting their detrimental effects could improve recovery in this devastating condition.

We recently found that rats with cervical SCI had an expanded IgM response, as shown by early extravasation of IgM immunoglobulin in the lesioned spinal cord and by chronically increased counts of IgM plasma cells in the spleen after injury (Ulndreaj et al., 2017). Research in other diseases suggests that IgM immunoglobulin is a key regulator of IgG-mediated autoimmunity (for review, see Ehrenstein and Notley, 2010). As such, some IgM autoantibodies have been shown to have protective effects in autoimmune conditions such as atherosclerosis and systemic lupus erythematosus (SLE). For example, increased levels of IgM autoantibodies against oxidized low-density lipoprotein (ox-LDL) and phosphorylcholine were associated with protection against atherosclerosis when adjusted for age, gender, smoking, total cholesterol levels and other factors (Su et al., 2006). Also, a lower ratio (below 0.8) of serum IgG/lgM autoantibodies against dsDNA was correlated with an absence of nephritis in patients with SLE (Förger et al., 2004). IgM immunoglobulin is also protective against infections (Boes et al., 1998a; Baumgarth et al., 2000, 2005), which are critically important in patients with $\mathrm{SCl}$, as they can modulate neurologic recovery (Failli et al., 2012; Kopp et al., 2017) and constitute the most frequent co-morbidity (DeVivo et al., 1999). Lastly, IgM is the carrier and a negative regulator of apoptosis inhibitor of macrophage (AIM) protein (Hiramoto et al., 2018; Miyazaki et al., 2018). AIM, also known as CD5L/Spalpha/API6, is associated with autophagy and efferocytosis (Sanjurjo et al., 2015), and it is one of the most highly upregulated genes early on after SCI (Zhu et

This work was supported by the Paralyzed Veterans of America as well as the Gerry and Tootsie Halbert Chair in Neural Repair and Regeneration (M.G.F.).

Acknowledgements: We thank Dr. Emina Torlakovic for assessing lung inflammation in mice with $\mathrm{SCl}$ at two weeks after injury. Also, we thank Behzad Azad for assistance with animal care and with the Basso Mouse Scale and grip strength tests, Sadiya Yousef for assistance with animal care, Alejandro Jose for assistance with mouse breeding and ELISA protocol optimizations, and Yang Liu for assistance with mouse breeding.

Correspondence should be addressed to Michael G. Fehlings at michael. fehlings@uhn.ca.

https://doi.org/10.1523/ENEURO.0491-19.2021

Copyright (C) 2021 Ulndreaj et al.

This is an open-access article distributed under the terms of the Creative Commons Attribution 4.0 International license, which permits unrestricted use, distribution and reproduction in any medium provided that the original work is properly attributed. al., 2017). Importantly, disruption of AIM's signaling by deletion of its receptor CD36 has been shown to result in improved neurobehavioral recovery following $\mathrm{SCl}$ in mice (Zhu et al., 2017).

Given this background, we posited that the expanded IgM response observed previously in our cervical $\mathrm{SCl}$ study could be a compensatory mechanism to limit the production of detrimental IgG autoantibodies observed post-SCI (Ulndreaj et al., 2017). Therefore, we hypothesized that mice deficient in IgM immunoglobulin will have impaired recovery after $\mathrm{SCl}$. By inducing cervical $\mathrm{SCl}$ in a mouse model that lacks the secretory form of IgM immunoglobulin [lgM-knock-out (KO); Boes et al., 1998b], we show that lack of IgM results in the enhanced deposition of IgG antibodies in the spinal cord early on (two weeks) after injury coupled with a widespread inflammatory response in the spinal cord. Chronically (10 weeks after injury), these IgM-KO mice presented with worse locomotor recovery, increased lesion size and less white matter preservation. Thus, this study provides evidence for the protective role of IgM immunoglobulin following cervical SCl.

\section{Materials and Methods}

\section{Mice}

All animal procedures were approved by the University Health Network Animal Care Committee and experiments were conducted according to the Guide to the Care and Use of Experimental Animals designed by the Canadian Council of Animal Care. Adult female B6;129S4-lghm ${ }^{t m 1 C h e}$, $\mathrm{J}$ mice were obtained from The Jackson Laboratory (JAX stock \#003751; Boes et al., 1998b) and were subsequently bred at the Krembil Discovery Research Animal Facility. In these mice, the $\mu_{\mathrm{s}}$ exon encoding the secreted form of the $\mu$ heavy chain, and its three downstream poly $(A)$ sites, are replaced by the $\mu_{\mathrm{m}}$ exon which encodes the constant region of the mu4 exon and the exon encoding the membranebound form of IgM (Boes et al., 1998b). For this study we bred heterozygotes and used mice that were homozygous for the $\mu_{\mathrm{m}}$ exon (here referred to as IgM-KO or KO) and littermate mice that were homozygous for the $\mu_{\mathrm{s}}$ exon [here referred to as IgM-wild-type (WT) or WT]. As a result, the lgM$\mathrm{KO}$ mice are deficient of secretory IgM immunoglobulin, although they express surface bound IgM and can classswitch into lgG immunoglobulin (Boes et al., 1998b).

\section{C6/C7 SCI model}

$\mathrm{SCl}$ at the $\mathrm{C6} / \mathrm{C} 7$ level was induced in female adult mice as previously established in our laboratory (Forgione et al., 2017). Blood was collected via the saphenous vein from all animals $24 \mathrm{~h}$ before surgery to establish baseline (BSL) levels of serum immunoglobulin. To induce C6/C7 $\mathrm{SCl}$, anesthesia was achieved by isoflurane (2\%) delivered in a 1:1 mixture of $\mathrm{O}_{2} / \mathrm{N}_{2} \mathrm{O}$ throughout the procedure. Following skin incision and muscle retraction between $\mathrm{C} 5$ and T2, the C6 and C7 laminae were removed. A microrongeur was carefully used to widen the laminectomized area and a 5.25-g modified aneurysm clip was applied to compress the $\mathrm{C} 6$ level for $40 \mathrm{~s}$. Next, a small piece of 
Surgifoam (Ethicon) was used to cover the injured area, followed by muscle and skin suturing. Mice received subcutaneous buprenorphine $(0.05 \mathrm{mg} / \mathrm{kg}$, twice daily for $3 \mathrm{~d})$ and saline ( $1 \mathrm{ml}$ daily for $7 \mathrm{~d}$ ) to prevent pain and dehydration, respectively. Sham mice underwent all above procedures, except for clip compression. All groups were housed in standard mouse cages (a maximum of five animals per cage), which were placed in a warm chamber of $27^{\circ} \mathrm{C}$ and $50 \%$ humidity. In mice with $\mathrm{SCl}$, bladders were expressed manually three times a day until bladder function returned to normal. Lastly, antibiotics (Clavamox) were delivered in drinking water for two weeks to prevent infection postoperatively. Animals were sacrificed at 2 and 10 weeks after injury. The two-week study was replicated whereby two independent experimenters (A.U. and N.F.) performed surgeries, performed behavioral tests and collected tissues for subsequent analyses. Since the study cohorts showed similar neurobehavioral outcomes (data not shown) for all subsequent assessments in the study, samples were retrieved randomly from the two cohorts to minimize bias.

\section{Behavioral analyses}

Mice underwent locomotor and grip strength tests to assess their neurologic recovery at selected time points after SCl. At weeks 1-3 post-SCl, we used the Basso Mouse Scale (BMS) test and the grip strength test to assess locomotion and forelimb grip recovery, respectively (Forgione et al., 2017). For BMS testing, animals were placed individually in an open field and allowed to locomote for 5 min during which time they were scored using a previously-established 10-point scale (0-9; Basso et al., 2006). For the grip strength test, the SDI Grip Strength System model DFM-10 (San Diego Instruments) was used. In this test, forelimb motor function was assessed based on the animal's ability to pull a metal grid located on an electronic grip strength meter. Each trial consisted of five separate pulls. The highest and lowest forces were omitted and the remaining three were averaged, as previously reported (Forgione et al., 2017).

At weeks 4-10 post-SCI, we used the CatWalk XT 10.6 system (Noldus Information Technology) to assess neurologic recovery in the forelimbs and hindlimbs. Of note, the CatWalk test could not be performed before the fourth week after injury as the animals were unable to complete the test consistently. In this study, we collected a minimum of three appropriate runs per animal at 4, 8, and 10 weeks post-SCl. However, for analysis, we only considered runs demonstrating a complete gait pattern, where maximum speed variation within each run was $<50 \%$, and the average speed between runs was not significantly different (Batka et al., 2014; Vidal et al., 2017). Additionally, data from animals that were unable to perform the test reliably for reasons that were not SCl-related (such as grooming, exploring the device during the test, etc.) were not collected for analysis. The parameters selected for analysis were stride length, print area, swing speed, swing time, step sequence regularity and average body speed, as previously reported (Forgione et al., 2017). All above tests were performed by one experimenter who was blinded to the groups.

\section{Tissue collection and processing}

At 2 and 10 weeks after injury, animals received an overdose of inhalant isoflurane and tissues were collected in the following order. Blood was collected from the heart and was left to clot at room temperature (RT) for at least 30 min for serum preparation for ELISA to confirm the absence of secretory IgM in KO mice and for the quantification of serum $\lg G$ and $\operatorname{lgM}$. Next, animals were transcardially perfused with ice-cold PBS followed by isolation and processing of tissues of interest.

The bladder and a piece of the colon from each animal were weighed, homogenized in sterile PBS, serially diluted and then cultured in standard LB agar plates for 24 $\mathrm{h}$ at $37^{\circ} \mathrm{C}$. The lungs were fixed in $4 \%$ paraformaldehyde (PFA) for $30 \mathrm{~min}$ and then in formalin overnight, followed by embedding, sectioning and staining for histology assessment as previously described (Ulndreaj et al., 2017). Spinal cords were fixed in 4\% PFA-PBS for $3 \mathrm{~h}$, then incubated in $10 \%$ sucrose $(\mathrm{w} / \mathrm{v})$-PFA for $3 \mathrm{~h}$, followed by an overnight incubation in $20 \%$ sucrose $(\mathrm{w} / \mathrm{v})-\mathrm{PBS}$ at $4^{\circ} \mathrm{C}$. A $1-\mathrm{cm}$-long section of the cervical cord centered at the injury epicenter was further selected for sectioning and $30-$ $\mu \mathrm{m}$-thick cryosections were stored at $-80^{\circ} \mathrm{C}$ before use for immunofluorescence staining.

\section{Quantitative lesion analysis}

Lesion analysis was performed at 2 and 10 weeks post$\mathrm{SCl}$. Thirty-micrometer-thick sections at $600-\mu \mathrm{m}$ intervals were stained with luxol fast blue (LFB) and hematoxylineosin (HE). Stereology was conducted using a Nikon Eclipse E800 microscope with a motorized stage and Stereolnvestigator software (MBF Biosciences). Lesion volume and spared gray/white matter volume were quantified for each section using the Cavalieri Estimator function. Spared gray matter was considered as the non LFBstained area displaying normal cytoarchitecture and easily distinguishable neuronal cell bodies. Spared white matter was considered as the LFB-stained area with normal architecture and non-lesional tissue. As previously reported (Forgione et al., 2017), here we defined lesional tissue as areas with loss of normal cytoarchitecture, absence of neuronal cell bodies, presence of fibrotic and/or glial scar tissue, infiltrated immune cells, as well as presence of vacuoles and loss of LFB stain (in gray matter).

\section{Immunofluorescence assessments in the lesioned spinal cord}

IgG deposition in the injured spinal cord

IgG deposition in the lesioned spinal cord was assessed by quantifying the \% area of $\mathrm{lg} G+$ immunofluorescent signal at 2 and 10 weeks post-SCl, following a previously reported protocol (Ulndreaj et al., 2017). Of note, this method is not sensitive to the intensity of the detected signal, but rather it semi-quantifies the spread of the $\lg G$ content on the tissue. Thus, IgG deposition refers to the degree of IgG spread on the tissue, expressed as percent of the total spinal cord section.

In brief, following air-drying and rehydration in PBS, cryosections were blocked with $5 \%$ goat serum $+1 \%$ 
$\mathrm{BSA}+0.3 \%$ Triton $\mathrm{X}-100$ in PBS for $1 \mathrm{~h}$ at RT. Cy3-conjugated goat anti-mouse $F\left(a b^{\prime}\right)_{2}$ IgG antibody (1:250, Jackson ImmunoResearch) and 4',6-diamidino-2-phenylindole (DAPI; 1:250) were added to the slides and incubated overnight at $4^{\circ} \mathrm{C}$. Of note, a $\mathrm{F}\left(\mathrm{ab} \mathrm{b}^{\prime}\right)_{2}$ IgG detecting antibody was used to minimize labeling of $F c$ receptors in the injured parenchyma. Sections were washed four times with PBS and slides were cover-slipped with Mowiol mounting medium (Sigma). To avoid staining variability, all samples from the same time point were stained simultaneously.

Samples were selected randomly for imaging and images were acquired as close together as possible. For the two-week time point, a Nikon Eclipse E800 microscope at $10 \times$ magnification was used. The threshold was set such that the brightest sections (injury epicenter) were not overexposed yet signal from the least bright sections could still be detected. A similar procedure, although using a Nikon eclipse Ti C2+ inverted confocal microscope, was followed for the 10-week time point. At both time points, all settings were kept constant during imaging. Signal from spinal cord sections, excluding the dura, was measured with the appropriate plugin in ImageJ software and assessed under identical settings. The IgG+ area was expressed as \% of the total area of the spinal cord section.

\section{Complement-fixing IgGs}

Complement fixation by deposited IgGs in the spinal cord was assessed in spinal cord sections with the highest IgG signal. These sections, which were located $-1200,-600$, and $+600 \mu \mathrm{m}$ from the injury epicenter, were co-stained for IgG and complement C3b protein and the amount of complement fixing IgGs was semiquantified based on the IgG+/C3b+ positive immunofluorescent area. Briefly, sections were first stained for IgG as described above. Next, they were incubated with anti-mouse C3b-FITC antibody (1:100, Cederlane, clone $11 \mathrm{H} 9$ recognizing $\mathrm{C} 3 / \mathrm{C} 3 \mathrm{~b} / \mathrm{iC} 3 \mathrm{~b})$ and DAPI (1:250) diluted in $5 \%$ goat serum $+1 \%$ BSA $+0.3 \%$ Triton $X-$ 100 in PBS, overnight at $4^{\circ} \mathrm{C}$. Lastly, sections were washed, cover-slipped and imaged with a Nikon eclipse $\mathrm{Ti}$ C2 + inverted confocal microscope, as described above. For each section, the area of positive immunofluorescence from IgG alone, C3b alone and IgG and $\mathrm{C} 3 \mathrm{~b}$ signal was estimated with ImageJ and expressed as $\%$ of the total area of the spinal cord section. Then, the obtained values for the three sections (representing distances $-1200,-600$, and $+600 \mu \mathrm{m}$ from the injury epicenter) were averaged per animal.

\section{Serum IgG and IgM immunoglobulin levels}

Serum IgG and IgM immunoglobulin was quantified by ELISA developed in-house. Briefly, standard 96-well plates were coated with $2 \mu \mathrm{g} / \mathrm{ml}$ of either capturing antimouse IgG antibody (Abcam) or anti-mouse IgM antibody (Abcam, ab 9175) O/N at $4^{\circ} \mathrm{C}$. Following one wash with PBS, plates were blocked with $4 \%$ goat serum in PBS for $2 \mathrm{~h}$ at RT. Next, serum diluted in $4 \%$ goat serum was added at 1:50,000 (for detection of $\mathrm{IgG}$ ) and at 1:10,000 (for detection of $\operatorname{lgM}$ ) and incubated for $4 \mathrm{~h}$ at RT. Mouse
IgG (Sigma, 15381) or IgM (BioLegend, 401601, clone $\mathrm{MM}-30$ ) purified from mouse serum was serially diluted in $1: 2$, starting from $10 \mu \mathrm{g} / \mathrm{ml}$, to create a standard curve in every plate ranging from $10 \mu \mathrm{g} / \mathrm{ml}$ to $9.8 \mathrm{ng} / \mathrm{ml}$. Plates were then washed with $0.05 \%$ Tween in PBS and incubated for 30 min at RT with anti-mouse IgG-HRP (Sigma) or IgM-HRP (Abcam) antibody diluted 1:10,000 in 4\% goat serum. Following four washes, plates were incubated with UltraFast TMB ELISA substrate (ThermoFisher Scientific) followed by deactivation of the chromogenic reaction with sulfuric acid (2 M, Sigma). Samples and standards were run in duplicates. IgG and IgM concentration in serum was interpolated from the standard curve to which a 4PL nonlinear curve fit was applied using Prism (GraphPad) software.

\section{T-lymphocytes and microglia/macrophages}

T-lymphocyte infiltration and microglia/macrophages in the spinal cords of IgM-KO and WT mice were assessed by immunohistochemistry $\mathrm{IHC}$ at 2 and 10 weeks post-SCI in 11 sections per animal at $600-\mu \mathrm{m}$ intervals.

For IHC staining, sections were first blocked in $5 \%$ goat serum $+1 \%$ BSA $+0.3 \%$ Triton X-100 in PBS. Next, sections were incubated with primary antibodies against the T-cell marker CD3 (goat anti-mouse CD3, 1:1000, Alexa Fluor 568, BioLegend) or the macrophage marker CD11b (rat anti-mouse CD11b, 1:300, Millipore CBL1313) overnight at $4^{\circ} \mathrm{C}$. DAPI $(1: 250)$ was incubated with the antiCD3 primary antibody or with the secondary antibody in sections stained for CD11b (goat anti-rat IgG, 1:500, Alexa Fluor 488, Life technologies), also overnight at $4^{\circ} \mathrm{C}$.

Following imaging with a Nikon Eclipse E800 microscope at $10 \times$ magnifications, CD3 + or CD11b + immunofluorescent areas or cell counts were estimated by ImageJ.

\section{Myelin-engulfing macrophages}

Myelin-engulfing macrophages were assessed in sections with the most intense $\operatorname{lgG}$ deposition $(-1200,-600$, and $+600 \mu \mathrm{m}$ from the injury epicenter). To this end, the selected sections were co-stained for fluoromyelin and CD11b. First, sections were stained for CD11b (primary + secondary antibody) as described above. Next, following washes, sections were incubated with fluoromyelin (1:100, Life Technologies, F34652) and DAPI (1:250) in $5 \%$ goat serum $+1 \%$ BSA $+0.3 \%$ Triton $X-100$ in PBS, overnight. Images were acquired with a Nikon eclipse Ti $\mathrm{C} 2+$ inverted confocal microscope under identical settings for each marker. The area of positive immunofluorescence for each marker was estimated with ImageJ and expressed as \% of the total DAPI+ area of the spinal cord section. Here, we report averaged values that were obtained from three sections (representing distances $-1200,-600$, and $+600 \mu \mathrm{m}$ from the injury epicenter) per animal.

\section{Experimental design and statistical analysis}

Sample sizes for all experiments in this study were determined a priori based on previous studies with similar animal models and experimental design (Forgione et al., 2017; Ulndreaj et al., 2017). Considering the predefined 
sample size, samples that were assessed were selected randomly from the pool of all samples collected. All experimental assessments, data collection and analyses were performed by experimenters who were blinded to the study groups. All ImageJ analyses were performed in an automated fashion to minimize human bias.

Prism (GraphPad) and SPSS (IBM) were used for hypothesis-testing statistical analyses of all the data. Comparisons between two groups were conducted using Student's $t$ tests for parametric data, and MannWhitney tests for non-parametric data. Statistical comparisons for more than two groups were conducted with one-way ANOVA and Bonferroni post hoc tests for parametric data or with Kruskal-Wallis tests for non-parametric data, respectively. All tests were two-tailed and statistically significant differences were considered to be those with a $p \leq 0.05$. CatWalk data were first analyzed by repeated measures to reveal changes between groups over time (Table 1). Parameters that were shown by repeated measures tests to differ significantly between groups were further analyzed by one-way ANOVA and Bonferroni post hoc tests to compare groups within each time point. Results are shown as individual data points, with each data point representing one animal. Bars indicate mean \pm standard error of the mean (SEM) unless otherwise specified. Results from hypothesis testing statistical analyses are reported in the statistical table (Table 1).

Where possible, estimation statistical analyses reporting effect size, confidence intervals (Cls) and $p$ values of permutation $t$ tests, were performed according to (Ho et al., 2019) using the online tool (https://www.estimationstats.com). Briefly for these analyses, 5000 bootstrap samples were taken, and the $\mathrm{Cl}$ was bias-corrected and accelerated. For each permutation $p$ value, 5000 reshuffles of the control and test labels were performed. The $p$ values reported are the likelihood of observing the corresponding effect size, if the null hypothesis of zero difference is true. In this study, statistical significance of the permutation $p$ value was set to 0.05 and therefore, in the graphs of data where permutation $p$ values were $<0.05$, the significant difference is indicated accordingly with asterisks (Figs. $1 E-I, 3 E, 5 A, C-H, 6 B-E$ ). Table 2 summarizes the effect size (unpaired mean difference) of the difference between compared groups and the $95 \% \mathrm{Cl}$ with lower and upper bound, as well as the $p$ values of permutation tests. Gardner-Altman estimation plots were generated using the online tool (https://www.estimationstats.com) where possible (Figs. $1 E-I, 3 E, 5 A, 6 B-E)$. Such plots depict the compared groups and the mean difference between the groups as a bootstrap sampling distribution. The mean difference is depicted as a dot; the $95 \% \mathrm{Cl}$ is indicated by the ends of the vertical error bar. Of note, CatWalk data were analyzed by both types of statistical approaches. Three-way ANOVA with post hoc test was performed to look at the effect of genotype, time point and injury status on the selected CatWalk parameters (Table 1), whereas estimation statistics were used to compare the $\mathrm{WT}-\mathrm{SCl}$ and $\mathrm{KO}-\mathrm{SCl}$ only, within each time point.
CatWalk data were not graphed as Gardner-Altman plots for aesthetic reasons. Asterisks on the graphs representing CatWalk data refer to significant results from estimation statistics comparing WT-SCl and $\mathrm{KO}-\mathrm{SCl}$ within each time point of the study (Table 2).

\section{Results}

\section{IgM-KO mice show increased deposition of complement-fixing Ig $G$ antibodies}

Antibodies accumulate in the injured parenchyma during the subacute phase of cervical SCI in rats (UIndreaj et al., 2017) and during the chronic phase of thoracic SCl in mice (Ankeny et al., 2009). Such antibodies have been shown to be autoreactive (Ankeny et al., 2006, 2009; Ulndreaj et al., 2017) and pathogenic by activating the classical complement system pathway (Ankeny et al., 2009). As IgM has been shown to regulate IgG autoimmunity under normal conditions (Boes et al., 2000), we hypothesized that IgM-KO mice would have increased IgGantibody deposition in the lesioned spinal cord during the subacute phase of our cervical SCI model, compared with their WT counterparts.

In line with this hypothesis, we found enhanced IgG deposition in IgM-KO mice, as shown by increased \% area of $\mathrm{IgG}+$ immunofluorescence compared with WT mice (Fig. 1A,B; Table 1). Particularly at distances $-1200,-600$, and $+600 \mu \mathrm{m}$ from the injury epicenter, the deposited IgG was $\sim 125 \%$ higher in KO mice than in the WT group. However, the enhanced antibody accumulation did not appear to be sustained in the chronic phase of injury, as there was no significant difference in $\% \operatorname{lgG}+$ immunofluorescent area between injured IgM-KO and WT mice at 10 weeks post-SCI (Fig. 1C; Table 1).

To establish whether the IgG deposited in the spinal cord after injury could activate the complement system, we selected sections with the highest IgG accumulation (e.g., at distances $-1200,-600$, and $+600 \mu \mathrm{m}$ from the injury epicenter) and co-stained them for IgG and complement C3b protein (Fig. 1D). As expected, there was increased IgG deposition in IgM-KO mice in comparison to controls (Fig. 1E; Table 2). Moreover, the IgG-C3b costained area was significantly larger in IgM-KO mice than in WT controls with $\mathrm{SCl}$, indicating enhanced complement-fixing activity of deposited IgG in the spinal cord of KO mice (Fig. 1F; Table 2). However, C3b deposition alone was not significantly different between IgM-KO mice and WT controls with SCI (Fig. 1G; Table 2) suggesting that lack of IgM does not affect complement deposition through all pathways, but rather complement deposition through the classical (antibody-mediated) pathway. Of note, one cannot exclude the possibility that lack of statistical difference (effect size 12.5, 95\%Cl: 1.48, 23.1, permutation $p=0.116$; Table 2) between the groups in Figure $1 G$ could be because of increased variance in the WT samples.

To exclude Fc-mediated binding of the labeling antiC3b antibody in the spinal cord, in our optimization assays we used a mix of Fc blocking peptides (Innovex, 
Table 1: Hypothesis testing statistics table showing the statistical tests used in the study and respective results

\begin{tabular}{|c|c|c|c|c|c|c|c|}
\hline Figure & Panel & Measure & $\begin{array}{l}\text { Groups (sample } \\
\text { size) }\end{array}$ & Test & Details & Statistic & $p$ value \\
\hline \multirow[t]{9}{*}{1} & \multirow[t]{4}{*}{$B$} & \multirow{4}{*}{$\begin{array}{l}\text { Effect of secretory IgM on the \% area of } \\
\operatorname{lgG} \text { deposition at } 2 \text { weeks post-SCl }\end{array}$} & \multirow{4}{*}{$\begin{array}{l}\mathrm{KO}(4), \mathrm{WT}(5) \\
\text { mice }\end{array}$} & \multirow{2}{*}{$\begin{array}{c}\text { Two-way ANOVA Sidak's post hoc to compare be- } \\
\text { tween KO and WT mice for each distance point }\end{array}$} & Effect of genotype & $F=21.31$ & $<0.0001$ \\
\hline & & & & & Section $-1200 \mu \mathrm{m}$ & $t=3.528$ & 0.0078 \\
\hline & & & & \multirow[t]{2}{*}{ Factor 1 (genotype), factor 2 (distance from epileft) } & Section $-600 \mu \mathrm{m}$ & $t=3.513$ & 0.0082 \\
\hline & & & & & Section $600 \mu \mathrm{m}$ & $t=2.957$ & 0.0445 \\
\hline & C & $\begin{array}{l}\text { Effect of secretory IgM on the \% area of } \\
\text { IgG deposition at } 10 \text { weeks post-SCI }\end{array}$ & $\begin{array}{l}\mathrm{KO}(4), \mathrm{WT}(4) \\
\text { mice }\end{array}$ & $\begin{array}{l}\text { Two-way ANOVA } \\
\text { Factor } 1 \text { (genotype), factor } 2 \text { (distance from epileft) }\end{array}$ & Effect of genotype & $F=1.965$ & 0.1657 \\
\hline & \multirow[t]{4}{*}{$H$} & \multirow[t]{4}{*}{$\begin{array}{l}\text { Effects of secretory IgM on levels of } \\
\text { serum IgG immunoglobulin }\end{array}$} & $\begin{array}{l}\text { KO: } \operatorname{BSL}(9) \text {, } \\
2 \text { weeks }(5), \\
10 \text { weeks }(7) \text { mice }\end{array}$ & \multirow[t]{4}{*}{$\begin{array}{l}\text { One-way ANOVA } \\
\text { Holm-Sidak's multiple comparisons test }\end{array}$} & $\begin{array}{l}\text { One-way ANOVA be- } \\
\text { tween WT and KO }\end{array}$ & $F=6.694$ & 0.0002 \\
\hline & & & WT: BSL (10), & & BSL: (KO vs WT) & $t=0.760$ & 0.6995 \\
\hline & & & \multirow[t]{2}{*}{10 weeks $(6)$ mice } & & $\begin{array}{l}2 \text { weeks post-SCl: } \\
\text { (KO vs WT) }\end{array}$ & $t=1.950$ & 0.1662 \\
\hline & & & & & $\begin{array}{l}10 \text { weeks post-SCl: } \\
\text { (KO vs WT) }\end{array}$ & $t=0.330$ & 0.7431 \\
\hline \multirow[t]{13}{*}{2} & \multirow[t]{6}{*}{$B$} & \multirow{5}{*}{$\begin{array}{l}\text { Effect of secretory IgM on the \% area of } \\
\mathrm{CD} 3+\text { cell infiltration at } 2 \text { weeks post- } \\
\mathrm{SCl}\end{array}$} & \multirow{5}{*}{$\begin{array}{l}\mathrm{KO}(4), \mathrm{WT}(5) \\
\text { mice }\end{array}$} & Two-way ANOVA & Effect of genotype & $F=15.93$ & 0.0001 \\
\hline & & & & Sidak's post hoc & Section $-1200 \mu \mathrm{m}$ & $t=2.689$ & 0.0088 \\
\hline & & & & \multirow{2}{*}{$\begin{array}{l}\text { to compare between } \mathrm{KO} \text { and } \mathrm{WT} \text { mice for each dis- } \\
\text { tance point }\end{array}$} & Section $-600 \mu \mathrm{m}$ & $t=2.862$ & 0.0054 \\
\hline & & & & & Section 0 & $t=2.29$ & 0.0248 \\
\hline & & & & Factor 1 (genotype), factor 2 (distance from epileft) & Section $600 \mu \mathrm{m}$ & $t=2.776$ & 0.0069 \\
\hline & & $\begin{array}{l}\text { Effect of secretory IgM on the } \% \text { area of } \\
\text { CD3 }+ \text { cell infiltration at } 10 \text { weeks post- } \\
\text { SCI }\end{array}$ & $\begin{array}{l}\mathrm{KO}(4), \mathrm{WT}(5) \\
\text { mice }\end{array}$ & $\begin{array}{l}\text { Two-way ANOVA } \\
\text { Factor } 1 \text { (genotype), factor } 2 \text { (distance from epileft) }\end{array}$ & Effect of genotype & $F=0.827$ & 0.3659 \\
\hline & \multirow[t]{7}{*}{ C } & \multirow{5}{*}{$\begin{array}{l}\text { Effect of secretory lgM on CD3+ cell } \\
\text { counts at } 2 \text { weeks post-SCI }\end{array}$} & \multirow{5}{*}{$\begin{array}{l}\mathrm{KO}(5), \mathrm{WT}(5) \\
\text { mice }\end{array}$} & Two-way ANOVA & Effect of genotype & $F=9.394$ & 0.0029 \\
\hline & & & & Sidak's post hoc & Section $-1200 \mu \mathrm{m}$ & $t=2.000$ & 0.0486 \\
\hline & & & & \multirow{2}{*}{$\begin{array}{l}\text { to compare between } \mathrm{KO} \text { and WT mice for each dis- } \\
\text { tance point }\end{array}$} & Section $-600 \mu \mathrm{m}$ & $t=2.095$ & 0.039 \\
\hline & & & & & Section 0 & $t=2.275$ & 0.0253 \\
\hline & & & & Factor 1 (genotype), factor 2 (distance from epileft) & Section $600 \mu \mathrm{m}$ & $t=2.483$ & 0.0149 \\
\hline & & Effect of secretory lgM on CD3+ cell & KO (5), WT (5) & Two-way ANOVA & Effect of genotype & $F=7.335$ & 0.0081 \\
\hline & & counts at 10 weeks post-SCI & mice & $\begin{array}{l}\text { Sidak's post hoc } \\
\text { to compare between KO and WT mice for each dis- } \\
\text { tance point } \\
\text { Factor } 1 \text { (genotype), factor } 2 \text { (distance from epileft) }\end{array}$ & Section $-1800 \mu \mathrm{m}$ & $t=2.351$ & 0.021 \\
\hline 3 & $B$ & Effect of secretory $\operatorname{lgM}$ on the $\%$ area of & KO (4), WT (5) & Two-way ANOVA & Effect of genotype & $F=20.69$ & $<0.0001$ \\
\hline & & $\mathrm{CD} 11 \mathrm{~b}+$ cells at 2 weeks post-SCI & mice & Sidak's post hoc & Section $-1200 \mu \mathrm{m}$ & $t=2.471$ & 0.0157 \\
\hline & & & & to compare between $\mathrm{KO}$ and WT mice for each dis- & Section 0 & $t=3.031$ & 0.0033 \\
\hline & & & & tance point & Section $600 \mu \mathrm{m}$ & $t=2.800$ & 0.0065 \\
\hline & & & & Factor 1 (genotype), factor 2 (distance from epileft) & & & \\
\hline & & $\begin{array}{l}\text { Effect of secretory lgM on the } \% \text { area of } \\
\text { CD11b + cell at } 10 \text { weeks post-SCl }\end{array}$ & $\begin{array}{l}\mathrm{KO}(4), \mathrm{WT}(5) \\
\text { mice }\end{array}$ & $\begin{array}{l}\text { Two-way ANOVA } \\
\text { Sidak's post hoc } \\
\text { to compare between KO and WT mice for each dis- } \\
\text { tance point } \\
\text { Factor } 1 \text { (genotype), factor } 2 \text { (distance from epileft) }\end{array}$ & $\begin{array}{l}\text { Effect of genotype } \\
\text { No significant post } \\
\text { hoc difference }\end{array}$ & $F=5.069$ & 0.0272 \\
\hline & C & Effect of secretory IgM on CD11b+ cell & KO (5), WT (5) & Two-way ANOVA & Effect of genotype & $F=21.61$ & $<0.0001$ \\
\hline & & counts at 2 weeks post-SCI & mice & Sidak's post hoc & Section $-1200 \mu \mathrm{m}$ & $t=2.096$ & 0.039 \\
\hline & & & & $\begin{array}{l}\text { to compare between } \mathrm{KO} \text { and WT mice for each dis- } \\
\text { tance point } \\
\text { Factor } 1 \text { (genotype), factor } 2 \text { (distance from epileft) }\end{array}$ & Section $600 \mu \mathrm{m}$ & $t=2.566$ & 0.012 \\
\hline & & Effect of secretory IgM on CD11b+ cell & KO (5), WT (5) & Two-way ANOVA & Effect of genotype & $F=21.92$ & $<0.0001$ \\
\hline & & counts at 10 weeks post-SCI & mice & Sidak's post hoc & Section $-2400 \mu \mathrm{m}$ & $t=2.573$ & 0.0117 \\
\hline & & & & to compare between $\mathrm{KO}$ and WT mice for each dis- & Section $-1200 \mu \mathrm{m}$ & $t=2.421$ & 0.0175 \\
\hline & & & & tance point & Section $-600 \mu \mathrm{m}$ & $t=2.647$ & 0.0096 \\
\hline & & & & $\begin{array}{l}\text { Factor } 1 \text { (genotype), factor } 2 \text { (distance from epileft) } \\
\text { (Continued) }\end{array}$ & Section $1200 \mu \mathrm{m}$ & $t=2.074$ & 0.041 \\
\hline
\end{tabular}


Table 1: Continued

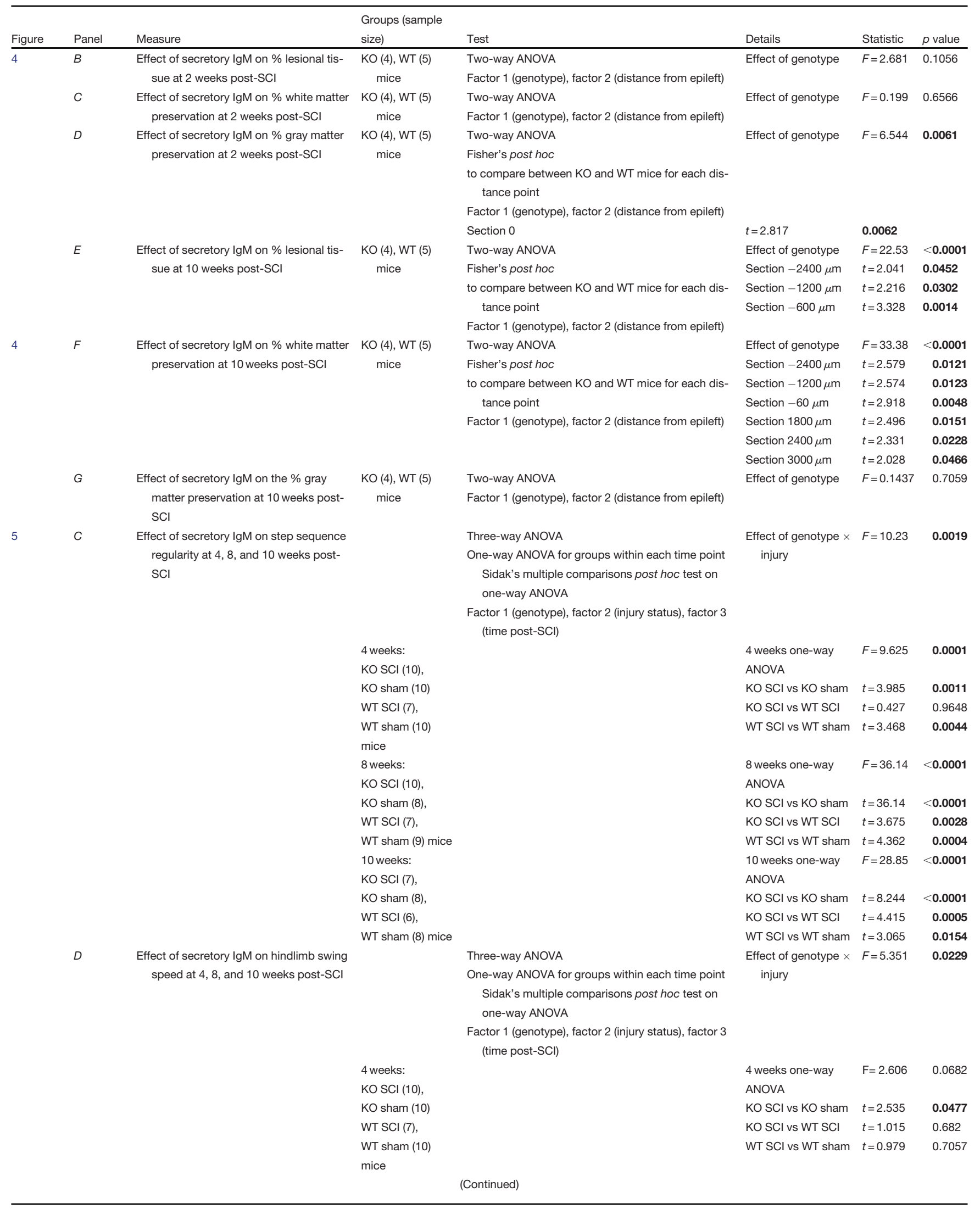


Table 1: Continued

\begin{tabular}{|c|c|c|c|c|c|c|c|}
\hline Figure & Panel & Measure & $\begin{array}{l}\text { Groups (sample } \\
\text { size) }\end{array}$ & Test & Details & Statistic & $p$ value \\
\hline \multirow[t]{34}{*}{5} & $D$ & Effect of secretory lgM on hindlimb swing & & & 8 weeks one-way & $F=3.214$ & 0.0358 \\
\hline & & speed at 4,8, and 10 weeks post-SCl & KO SCl (10), & & ANOVA & & \\
\hline & & & KO sham (8), & & KO SCl vs KO sham & $t=2.423$ & 0.0624 \\
\hline & & & WT SCI (7), & & KO SCl vs WT SCl & $t=2.372$ & 0.0699 \\
\hline & & & WT sham (9) mice & & WT SCI vs WT sham & $t=0.126$ & 0.999 \\
\hline & & & 10 weeks: & & 10 weeks one-way & $F=5.733$ & 0.0127 \\
\hline & & & $\mathrm{KO} \mathrm{SCl}(9)$ & & ANOVA & & \\
\hline & & & KO sham (8), & & KO SCl vs KO sham & $t=3.123$ & 0.0395 \\
\hline & & & WT SCI (6), & & KO SCl vs WT SCI & $t=2.474$ & 0.3076 \\
\hline & & & WT sham (8) mice & & & & \\
\hline & & & $\begin{array}{l}\text { WT SCl vs WT } \\
\text { sham }\end{array}$ & & $t=1.04$ & 0.668 & \\
\hline & $E$ & $\begin{array}{l}\text { Effect of secretory lgM on forelimb swing } \\
\text { speed at } 4,8 \text {, and } 10 \text { weeks post-SCl }\end{array}$ & & $\begin{array}{l}\text { Three-way ANOVA } \\
\text { One-way ANOVA for groups within each time point } \\
\text { Sidak's multiple comparisons post hoc test on } \\
\text { one-way ANOVA } \\
\text { Factor } 1 \text { (genotype), factor } 2 \text { (injury status), factor } 3 \\
\text { (time post-SCl) }\end{array}$ & $\begin{array}{l}\text { Effect of genotype } \times \\
\text { injury }\end{array}$ & $F=0.998$ & 0.3205 \\
\hline & & & 4 weeks: & & 4 weeks one-way & $F=5.912$ & 0.0024 \\
\hline & & & KO SCI (10), & & ANOVA & & \\
\hline & & & KO sham (10), & & KO SCl vs KO sham & $t=3.467$ & 0.0044 \\
\hline & & & WT SCI (7), & & KO SCl vs WT SCl & $t=0.139$ & 0.9987 \\
\hline & & & $\begin{array}{l}\text { WT sham (10) } \\
\text { mice }\end{array}$ & & WT SCI vs WT sham & $t=2.337$ & 0.075 \\
\hline & & & 8 weeks: & & 8 weeks one-way & $F=9.014$ & 0.0002 \\
\hline & & & KO SCI (12), & & ANOVA & & \\
\hline & & & KO sham (8), & & KO SCl vs KO sham & $t=4.364$ & 0.0004 \\
\hline & & & WT SCI (7), & & KO SCl vs WT SCl & $t=0.107$ & 0.9994 \\
\hline & & & WT sham (9) mice & & & & \\
\hline & & & $\begin{array}{l}\text { WT SCI vs WT } \\
\text { sham }\end{array}$ & & & $t=2.823$ & 0.0242 \\
\hline & & & 10 weeks: & & 10 weeks one-way & $F=6.61$ & 0.0017 \\
\hline & & & KO SCl (9), & & ANOVA & & \\
\hline & & & KO sham (8), & & $\mathrm{KO} \mathrm{SCl}$ vs KO sham & $t=3.418$ & 0.006 \\
\hline & & & $\begin{array}{l}\text { WT SCI (6), } \\
\text { WT sham (8) mice }\end{array}$ & & KO SCl vs WT SCI & $t=0.777$ & 0.8278 \\
\hline & & & $\begin{array}{l}\text { WT SCl vs WT } \\
\text { sham }\end{array}$ & & & $t=2.595$ & 0.0446 \\
\hline & $F$ & $\begin{array}{l}\text { Effect of secretory IgM on hindlimb print } \\
\text { area at } 4,8 \text {, and } 10 \text { weeks post-SCI }\end{array}$ & & $\begin{array}{l}\text { Three-way ANOVA } \\
\text { One-way ANOVA for groups within each time point } \\
\text { Sidak's multiple comparisons post hoc test on } \\
\text { one-way ANOVA } \\
\text { Factor } 1 \text { (genotype), factor } 2 \text { (injury status), factor } 3 \\
\quad \text { (time post-SCl) }\end{array}$ & $\begin{array}{l}\text { Effect of genotype } \times \\
\text { injury }\end{array}$ & $F=1.416$ & 0.2371 \\
\hline & & & 4 weeks: & & 4 weeks one-way & $F=0.641$ & 0.5941 \\
\hline & & & KO SCI (10), & & ANOVA & & \\
\hline & & & KO sham (10), & & KO SCl vs KO sham & $t=0.239$ & 0.9934 \\
\hline & & & WT SCI (7), & & KO SCl vs WT SCl & $t=1.082$ & 0.6375 \\
\hline & & & $\begin{array}{l}\text { WT sham (10) } \\
\text { mice }\end{array}$ & & WT SCI vs WT sham & $t=1.095$ & 0.6291 \\
\hline \multirow[t]{6}{*}{5} & $F$ & $\begin{array}{l}\text { Effect of secretory IgM on hindlimb print } \\
\text { area at } 4,8 \text {, and } 10 \text { weeks post-SCI }\end{array}$ & $\begin{array}{l}8 \text { weeks: } \\
\text { KO SCI (12), }\end{array}$ & & $\begin{array}{l}8 \text { weeks one-way } \\
\text { ANOVA }\end{array}$ & $F=1.1$ & 0.3635 \\
\hline & & & KO sham (8), & & KO SCl vs KO sham & $t=0.340$ & 0.9817 \\
\hline & & & WT SCI (7), & & KO SCl vs WT SCl & $t=1.393$ & 0.4349 \\
\hline & & & WT sham (9) mice & & WT SCI vs WT sham & $t=0.546$ & 0.9306 \\
\hline & & & & & & $F=8.787$ & 0.0003 \\
\hline & & & & (Continued) & & & \\
\hline
\end{tabular}


Table 1: Continued

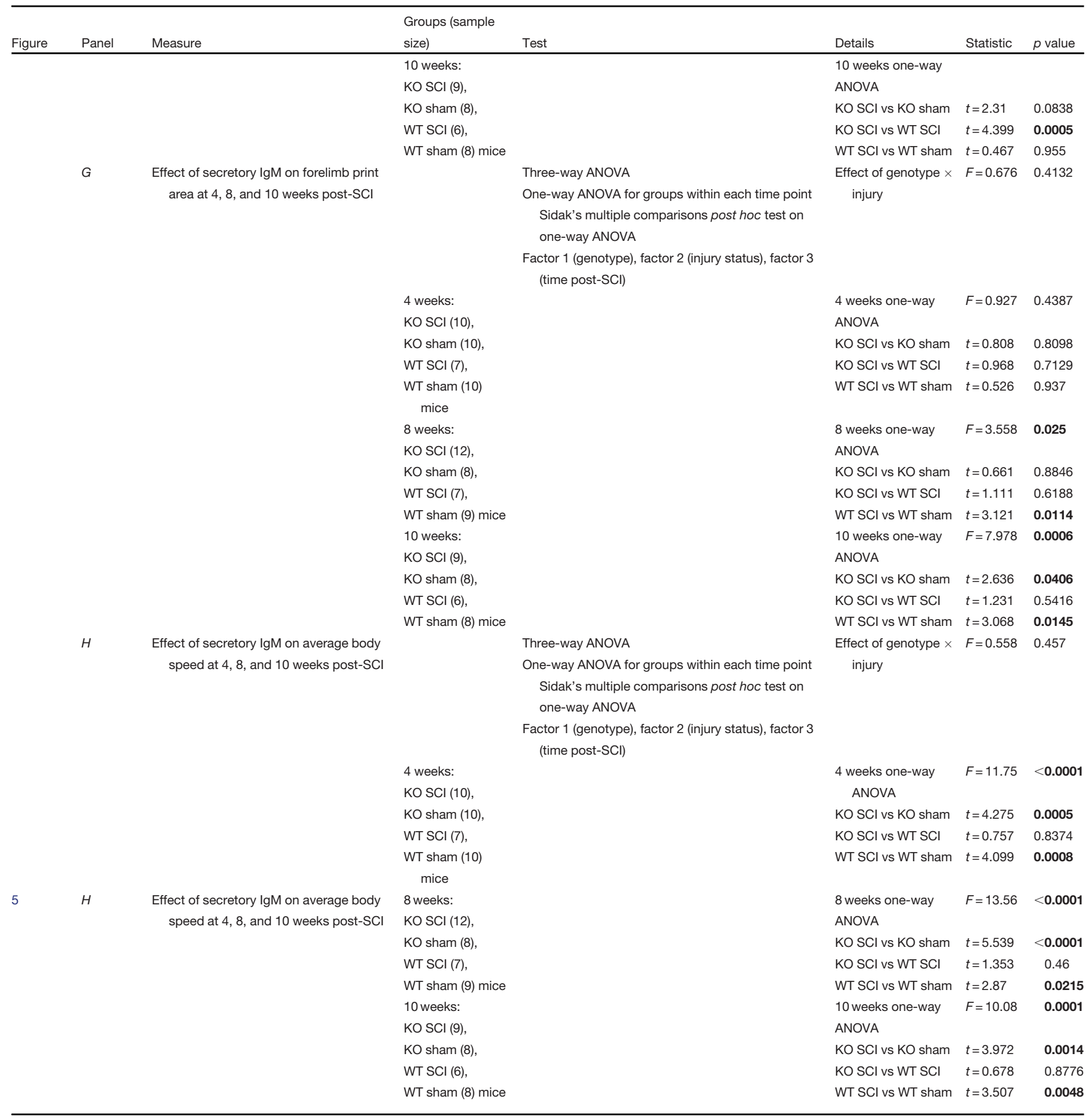

$p$ values $<0.05$ are shown in bold for emphasis.

\#NB30930) and compared binding of antibodies to untreated sections. However, we did not find a significant difference in binding of anti-C3b antibody between the samples treated with Fc block and the untreated samples, even in sections of high antibody binding such as the injury epicenter (data not shown). Thus, binding of the anti$\mathrm{C} 3 \mathrm{~b}$ antibody in our spinal cord sections was not Fcmediated.

Total levels of circulating IgG were similar between IgM-KO and WT mice at BSL (24 h before SCl) and at 2 and 10 weeks post-SCI (Fig. $1 H$; Table 1). This suggests that increased presence of parenchymal IgG deposition in IgM-KO mice at two weeks post-SCl is not because of higher circulating IgG levels in these mice. Moreover, IgG levels increased in both groups at 2 and 10 weeks post-SCl compared with their respective BSL levels (Fig. $1 \mathrm{H}$; Table 2). Lastly, while there was no detectable IgM immunoglobulin in $\mathrm{KO}$ mice before and after the injury, serum levels of IgM increased at two weeks following SCI (Fig. 1/; Table 2). 

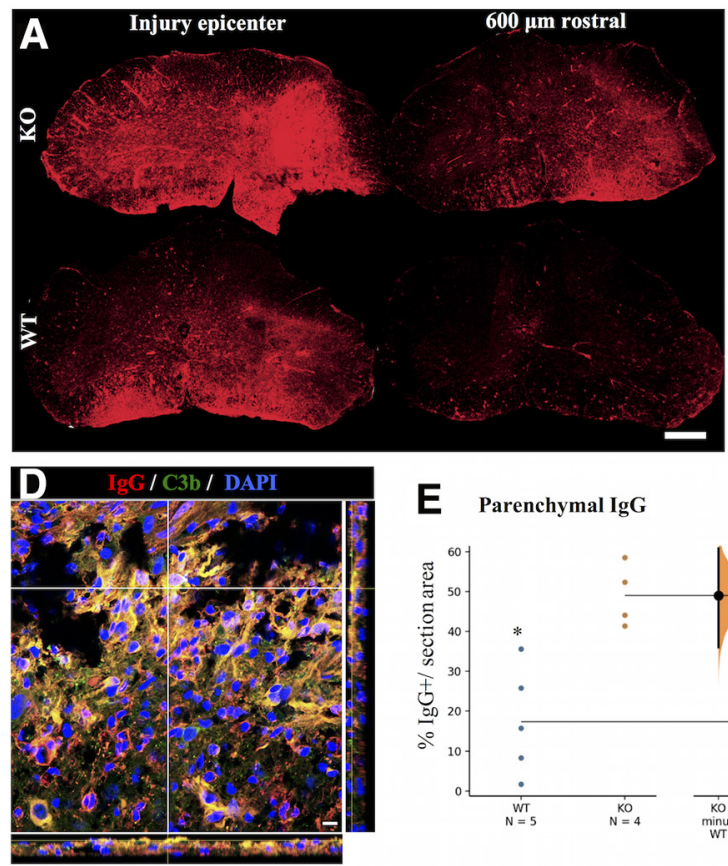

H Serum IgG in IgM-KO mice
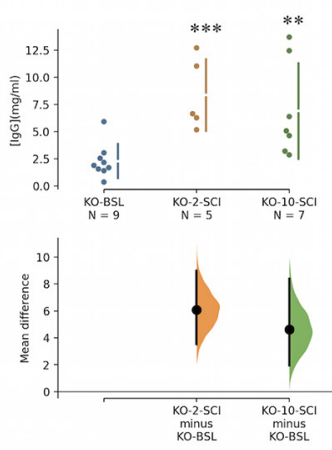

E Parenchymal IgG
B
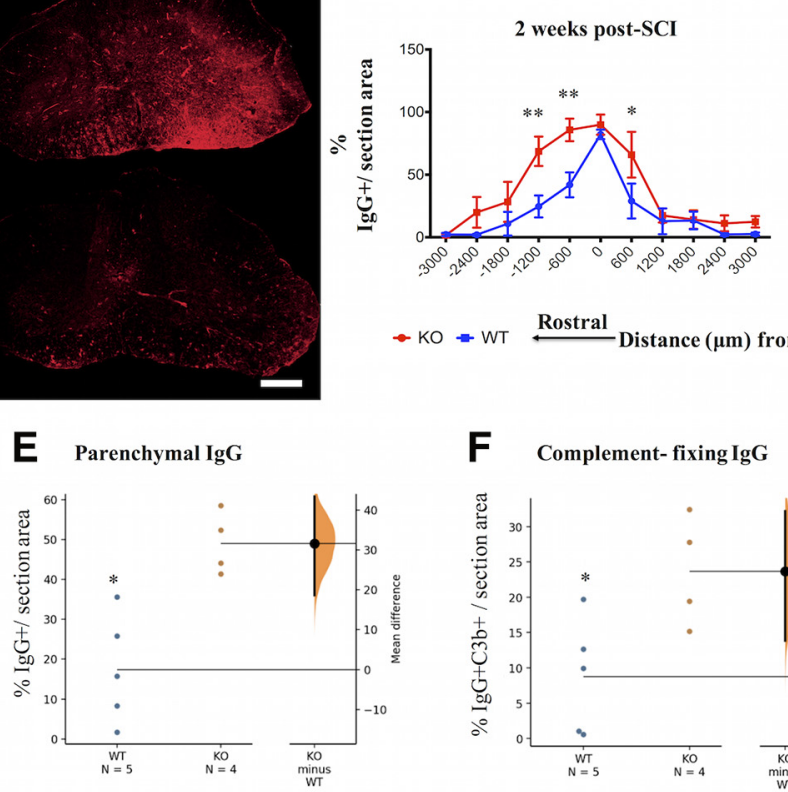

Serum IgG in WT mice
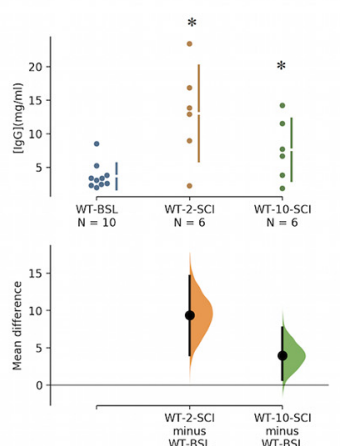

\section{C}

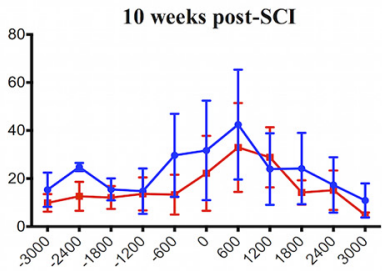

(0) $\stackrel{\text { Caudal }}{\longrightarrow}$
F Complement- fixing IgG

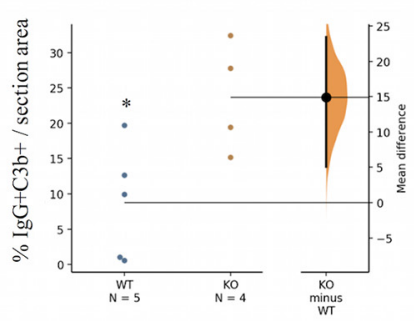

G Complement deposition

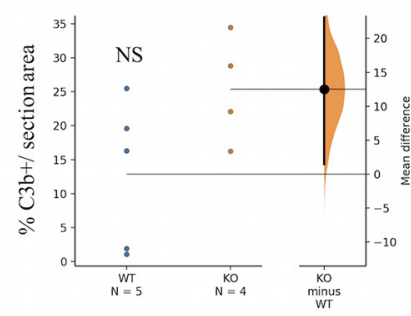

WT mice
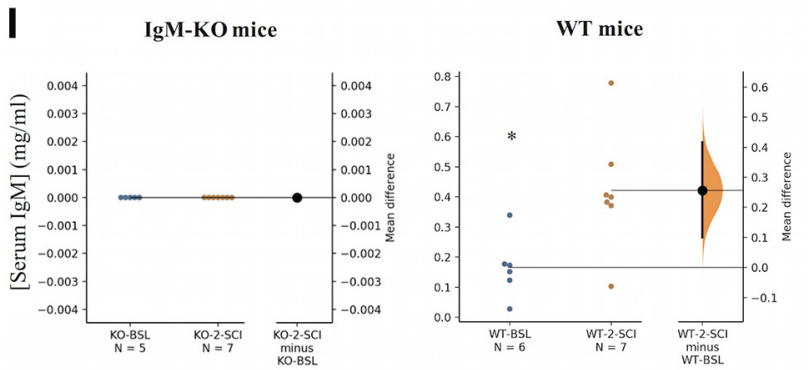

Figure 1. IgM KO mice have more parenchymal IgG antibodies with enhanced complement-fixing activity. $\boldsymbol{A}$, IgG deposition in spinal cord sections of IgM-KO and IgM-WT mice at two weeks post-SCI. Scale bar: $100 \mu \mathrm{m}$. B, Comparison of the \% detected IgG+ immunofluorescent area between groups at two weeks following SCI. See Table 1 for statistics details. C, Comparison of the \% detected IgG+ immunofluorescent area between groups at 10 weeks following SCl. See Table 1 for statistics details. $\boldsymbol{D}$, Representative section stained for IgG (red) and complement C3b protein (green). Yellow signal indicates co-localization of IgG and C3b. Scale bar: $10 \mu \mathrm{m}$. E-G, Gardner-Altman estimation plots of \% immunofluorescent area from deposited lgG, IgG+C3b, and C3b averaged between sections $-1200,-600$, and $+600 \mu \mathrm{m}$ from the injury epicenter, and normalized per section area $(N=4-5$ animals/group). See Table 2 for statistics details. $\boldsymbol{H}$, Gardner-Altman estimation plots of total serum IgG levels in lgM-KO and WT mice at BSL (pre-SCl) and at 2 and 10 weeks post-SCl. There is no difference in lgG levels between IgM-KO and WT mice within each time point (data not shown; see statistical Table 1 for details about WT vs KO comparisons). Serum IgG levels increase significantly after injury when compared with their BSL levels in IgM-KO and WT mice. See Table 2 for statistics details. I, GardnerAltman estimation plots of total serum IgM levels in IgM-KO and WT mice at BSL and at two weeks post-SCl, indicating a significant increase of IgM levels in WT mice, following SCI. See Table 2 for statistics details. NS = nonsignificant. Graphs $\boldsymbol{B}, \boldsymbol{C}$ : mean \pm SEM, ${ }^{\star} p<0.05$, ${ }^{\star *} p<0.01$ (see Table 1 for detailed $p$ values). Graphs $\boldsymbol{E}-\boldsymbol{I}$ : permutation $t$ test, ${ }^{*} p<0.05$, ${ }^{\star *} p<0.01$, ${ }^{\star \star \star} p<0.001$ (see Table 2 for detailed $p$ values).

\section{IgM-KO mice have more T-lymphocytes and microglia/macrophages with myelin-engulfing activity in the lesioned spinal cord}

Inflammation mediated by microglia/macrophages and T-lymphocytes is a well-known regulator of pathophysiology in SCl (for review, see Donnelly and Popovich, 2008). Thus, we asked whether the absence of IgM in mice with
$\mathrm{SCl}$ was linked to an enhanced presence of T-lymphocytes and microglia/macrophages. Indeed, IgM-KO mice showed larger $\mathrm{CD} 3+$ immunofluorescent areas and CD3 + cell counts, as compared with WT controls, at two weeks post-SCI (Fig. 2; Table 1). At 10 weeks post-SCI there was no difference in CD3+ immunofluorescence area between the IgM-KO and WT groups, but IgM-KO 
Table 2: Estimation statistics table showing effect size (unpaired means difference) with $95 \%$ Cls and permutation tests $p$ values as follows: effect size [CI width with lower bound, upper bound]

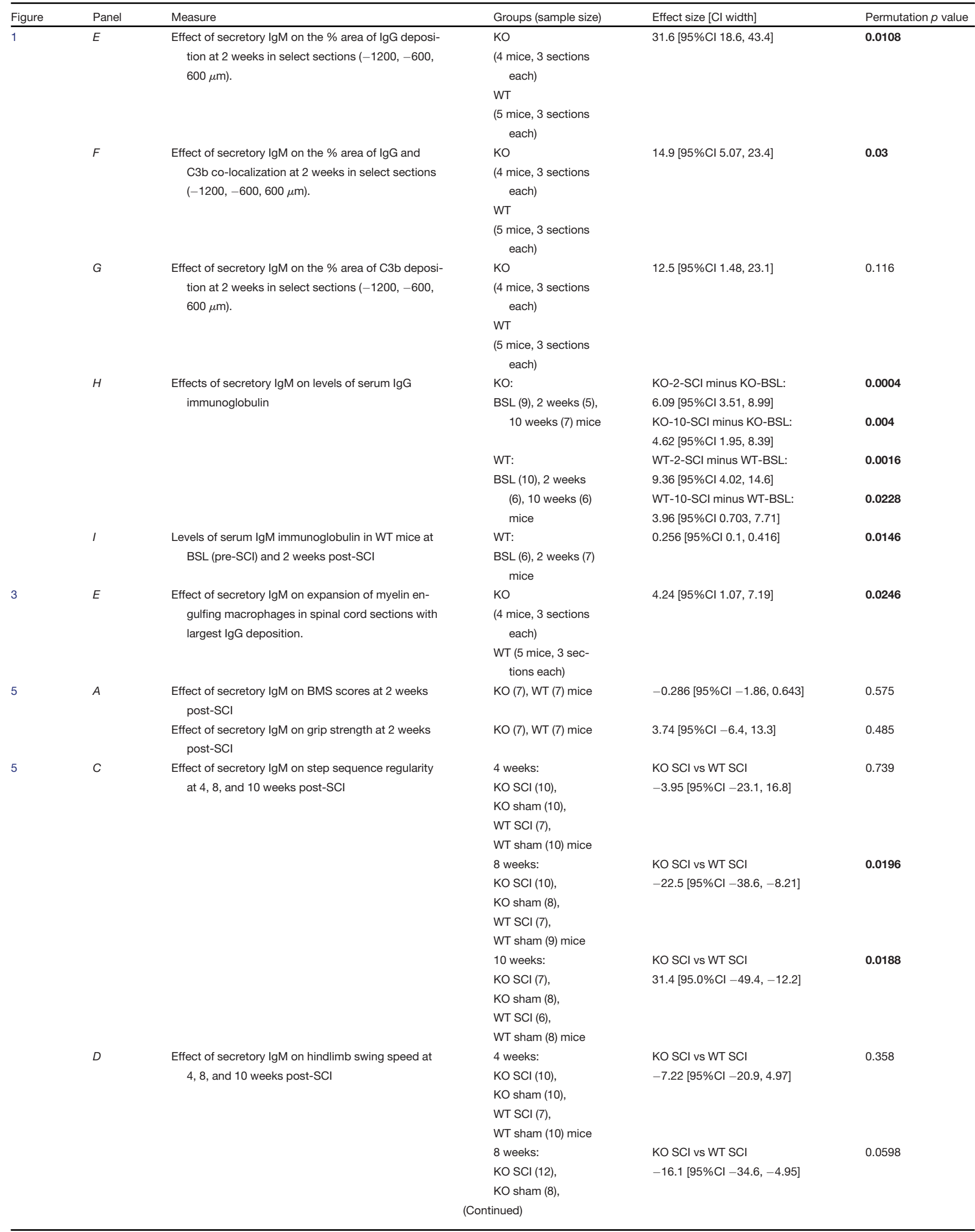


Table 2: Continued

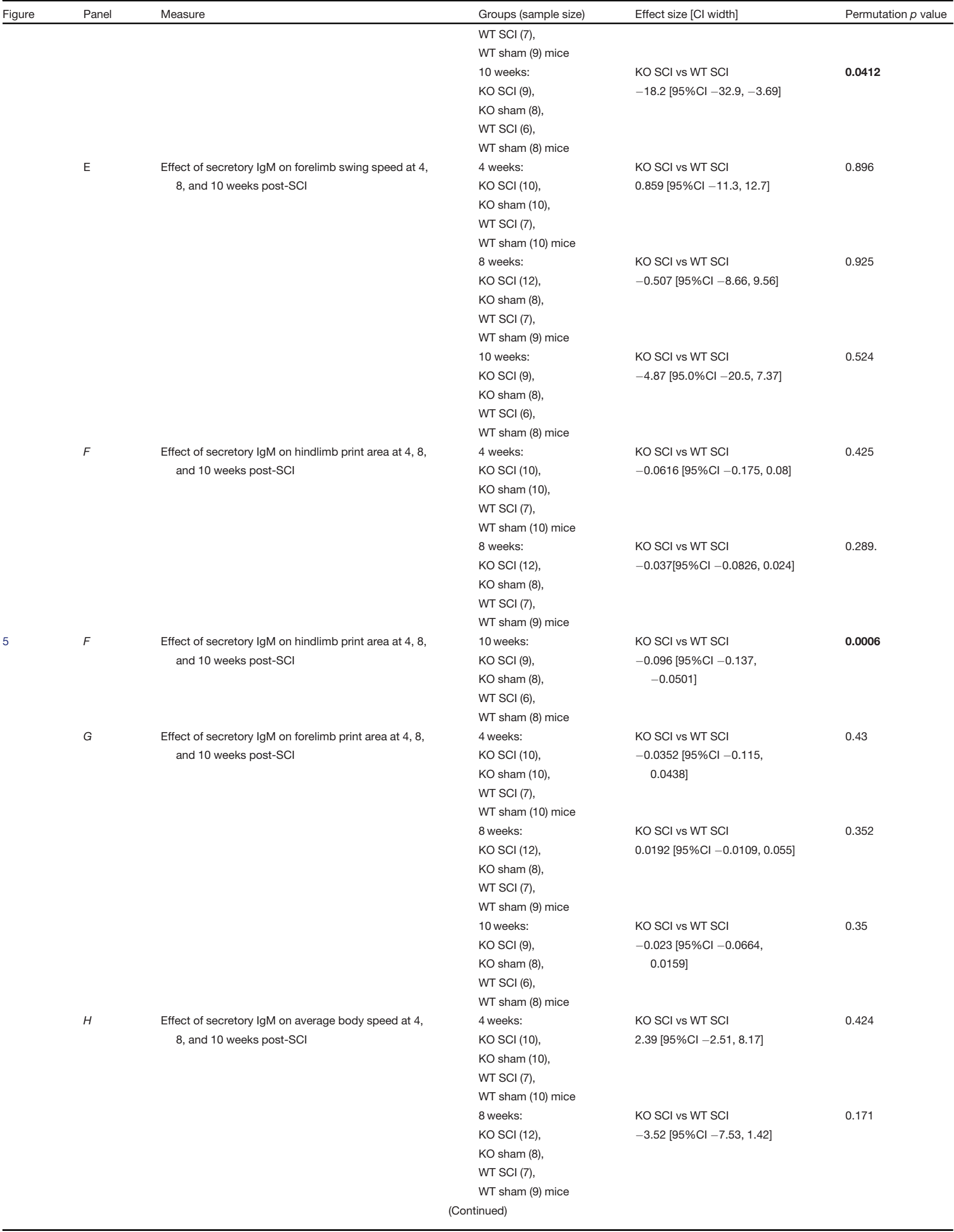


Table 2: Continued

\begin{tabular}{|c|c|c|c|c|c|}
\hline Figure & Panel & Measure & Groups (sample size) & Effect size $[\mathrm{Cl}$ width] & Permutation $p$ value \\
\hline & & & 10 weeks: & KO SCl vs WT SCl & 0.49 \\
\hline & & & $\mathrm{KO} \mathrm{SCl}(9)$ & $-2.31[95 \% \mathrm{Cl}-8.24,3.55]$ & \\
\hline & & & KO sham (8), & & \\
\hline & & & WT SCI (6), & & \\
\hline & & & WT sham (8) mice & & \\
\hline \multirow[t]{6}{*}{6} & $B$ & $\begin{array}{l}\text { Effect of secretory lgM on bacterial load in bladder at } \\
2 \text { weeks post-SCl }\end{array}$ & KO (7), WT (7) mice & $0.429[95 \% \mathrm{Cl} 0.0,1.29]$ & 0 \\
\hline & C & Effect of secretory IgM on bacterial load in colon at & KO (7), WT (6) mice & $1.29 \mathrm{e}+02[95 \% \mathrm{Cl}-2.01 \mathrm{e}+02$ & 0.877 \\
\hline & & 2 weeks post-SCI & $\begin{array}{l}\text { Upon log-transfor- } \\
\text { mation: }\end{array}$ & $7 e+02]$ & \\
\hline & & & KO (5), WT (6) mice & & \\
\hline & $D$ & $\begin{array}{l}\text { Effect of secretory IgM on body weight at } 2 \text { weeks } \\
\text { post-SCl }\end{array}$ & KO (7), WT (7) mice & $-1.54[95 \% \mathrm{Cl}-7.52,3.85]$ & 0.617 \\
\hline & $E$ & $\begin{array}{l}\text { Effect of secretory IgM on spleen weight at } 2 \text { weeks } \\
\text { post-SCl }\end{array}$ & KO (7), WT (7) mice & $0.005[95 \% \mathrm{Cl}-0.0206,0.0272]$ & 0.686 \\
\hline
\end{tabular}

$p$ values for permutation tests $<0.05$ are shown in bold for emphasis.

mice showed elevated CD3 + cell counts overall, and especially $1800 \mu \mathrm{m}$ rostrally from the injury epicenter (Fig. $2 C$; Table 1).

In line with our hypothesis, we also found significantly larger CD11b+ \%immunostained areas in IgM-KO mice than in WT mice at 2 weeks but not at 10 weeks (Fig. $3 A$, $B$; Table 1) of SCI. CD11b + cell counts were higher in IgM-KO mice at both 2 and 10 weeks after injury (Fig. $3 C$; Table 1).

Next, we asked whether these microglia/macrophages had engulfed myelin, and whether there was a difference between IgM-KO mice and WT mice regarding the extent of myelin engulfment by microglia/macrophages. To this end, we semi-quantified the \%area that was co-stained for CD11b and fluoromyelin (Fig. 3D) in sections with the highest IgG deposition (i.e., $-1200,-600$, and $+600 \mu \mathrm{m}$ from the injury epicenter) at two weeks post-SCI. Our data showed a significant increase in CD11b+fluoromyelin + areas in the spinal cords of IgM-KO mice compared with WT controls at two weeks of SCI (Fig. 3E; Table 2), suggesting enhanced myelin engulfment by microglia/macrophages in the absence of IgM immunoglobulin.

\section{IgM-KO mice have larger lesion size in comparison to WT mice following SCI}

We quantified the volume of lesional tissue and white/ gray matter sparing at 2 and 10 weeks post-SCl. Lesioned areas were present in both the gray and the white matter. In the gray matter, lesions had inflammation, apparent disruption of the normal cytoarchitecture along with fibrosis. In the white matter, lesions presented with inflammation, loss of LFB staining and vacuoles (Fig. 4A). There was no statistical difference between the groups in the volumes of lesional tissue (Fig. 4B; Table 1) or white matter preservation (Fig. 4C; Table 1) at two weeks of injury. However, the preserved gray matter was significantly lower in IgM KO mice, particularly at $600 \mu \mathrm{m}$ rostral from the injury epicenter (Fig. 4D; Table 1).

Of note, IgM KO mice had significant loss of neural tissue at 10 weeks post-SCl. Compared with their WT counterparts, IgM-KO mice with SCl had more lesional tissue, especially rostral to the injury epicenter (Fig. 4E; Table 1). Concomitantly, IgM-KO mice had less white matter preservation rostrally and caudally from the injury epicenter (Fig. 4F; Table 1), while both groups had similar gray matter preservation (Fig. 4G; Table 1) at 10 weeks after injury.

\section{IgM deficiency results in impaired locomotor recovery during the chronic phase of $\mathrm{SCl}$}

At two weeks post-SCl, IgM-KO mice and their WT counterparts showed similar locomotor and grip strength performance in BMS and grip strength tests, respectively (Fig. 5A; Table 2). However, at later time points, IgM-KO mice with $\mathrm{SCl}$ had impaired coordination and hindlimb function compared with their WT counterparts, based on their performance on the CatWalk test (Fig. 5B). In particular, injured $\mathrm{KO}$ mice had worse interlimb coordination compared with WT mice at 8 and 10 weeks post-SCI, as indicated by lower \% step sequence regularity indices [Fig. 5C; Table 1 (for multiple comparisons across all time points and groups); Table 2 (for estimation statistics comparing WT-SCl to $\mathrm{KO}-\mathrm{SCl}$ at each time point)]. By 10 weeks of injury, the difference between IgM-KO and WT mice with $\mathrm{SCl}$ was striking, with the regularity index ranging between $44-88 \%$ in WT mice, and $14-65 \%$ in KO mice.

Hindlimb swing speed was significantly impaired in KO mice compared with WT at 10 weeks of injury [Fig. $5 D$; Table 1 (for multiple comparisons across all time points and groups); Table 2 (for estimation statistics comparing WT-SCl to $\mathrm{KO}-\mathrm{SCl}$ at each time point)]. Forelimb swing speed was significantly decreased in both genotypes after $\mathrm{SCl}$ when compared with their sham counterparts (Fig. 5E; Table 1). However, the absence of IgM did not appear to affect forelimb swing speed, as injured WT and IgM-KO mice showed similar recovery (Fig. $5 E$; Table 2).

IgM-KO mice had significantly smaller hindlimb print areas than their WT counterparts at 10 weeks after injury (Fig. 5F; Table 2). In both genotype groups, forelimb print area was reduced after injury when compared with their sham counterparts (Fig. 5G; Table 1). However, there was 
2 weeks post-SCI

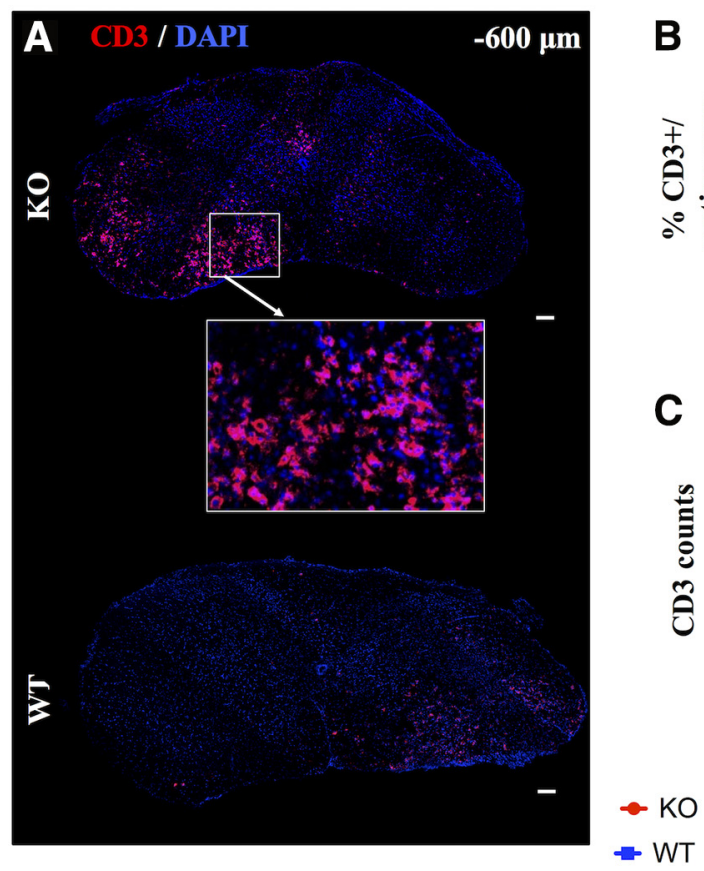

Rostral
B
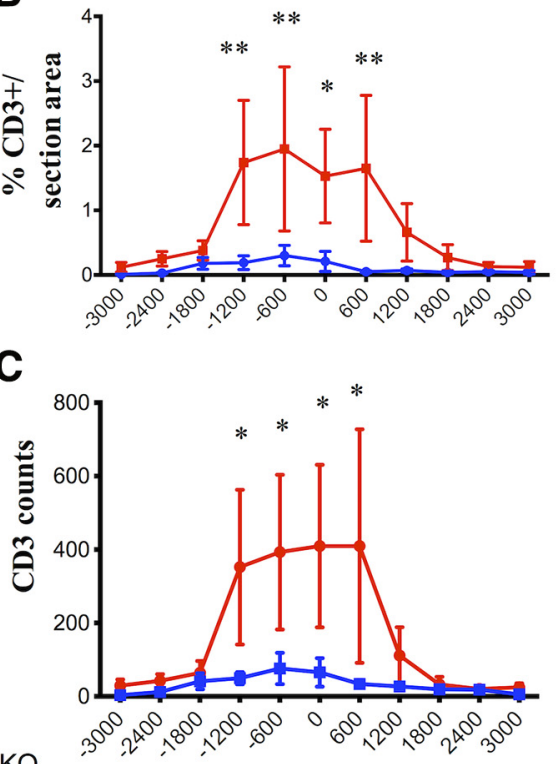

10 weeks post-SCI
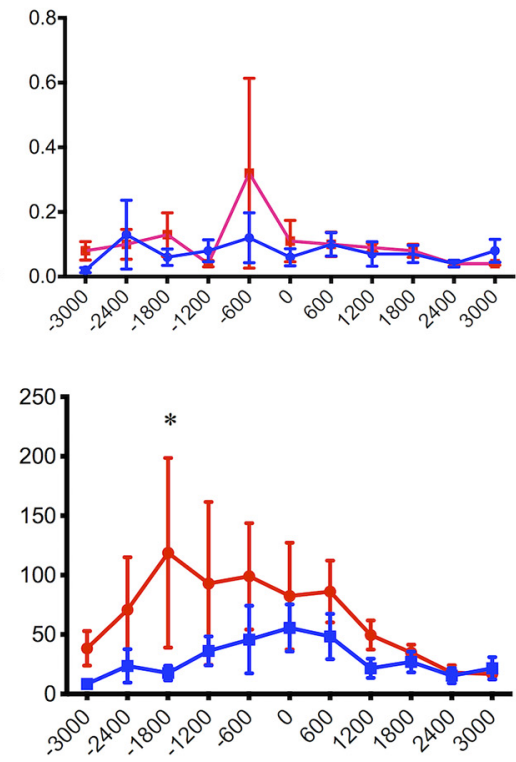

Distance $(\mu \mathrm{m})$ from injury epicenter $(0)$

Caudal

Figure 2. IgM-KO mice have increased T-lymphocyte infiltration compared with WT mice at two weeks post-SCl. $\boldsymbol{A}$, Representative sections stained for T-lymphocytes marker CD3 and DAPI in IgM-KO and WT mice at two weeks post-SCl. Quantification of \% CD3+ immunostained area/total spinal cord section area $(\boldsymbol{B})$ and CD3 cell counts $(\boldsymbol{C})$ rostro-caudally from the injury epicenter, at 2 and 10 weeks post-injury in IgM-KO and WT mice. $N=4-5$ mice/group (B), 5 mice/group (C), mean \pm SEM; ${ }^{*} p<0.05$, ${ }^{* *} p<0.01$ (see Table 1 for detailed statistical results).

no difference in forelimb print areas between IgM-KO and WT mice with SCI (Fig. 5G; Table 2). Despite the above differences in coordination, hindlimb swing speed and hindlimb print area between the IgM-KO and WT mice with $\mathrm{SCl}$, the average body speed was similar between IgM-KO and WT mice at all time points of the study [Fig. $5 \mathrm{H}$; Table 1 (for multiple comparisons across all time points and groups); Table 2 (for estimation statistics comparing $\mathrm{WT}-\mathrm{SCl}$ to $\mathrm{KO}-\mathrm{SCl}$ at each time point)].

\section{IgM deficiency does not result in respiratory tract infections or urinary tract infections (UTIs)}

Infections have been shown to negatively affect neurologic recovery in SCI (Failli et al., 2012). Respiratory tract infections and UTIs are common complications in patients with SCl (Garcia-Arguello et al., 2017). As the peripheral immune response is particularly suppressed during the subacute phase of C7/T1 SCl in rats (Ulndreaj et al., 2017), we hypothesized that IgM-KO mice would have increased bacteria in their bladders and signs of pneumonia in their lungs at two weeks post-SCI. To test this hypothesis, we quantified the bacterial load in bladders of IgM-KO and WT mice with $\mathrm{SCl}$ and assessed for signs of inflammation in the lungs (e.g., abnormal presence of macrophages, increased numbers of macrophages and abnormal tissue structure) at two weeks after injury. There were no signs of lung inflammation in IgM-KO mice compared with WT mice (Fig. 6A). In addition, we found no significant increase in bacterial counts in the bladders of IgM-KO mice compared with WT mice with SCI (Fig. 6B; Table 2). Similar microbial counts were found in gut cultures (isolated from the colon), which were used as a positive control for detection and culturing of bacteria (Fig. 6C; Table 2). Other important metrics of recovery from SCl (Brommer et al., 2016) such as body weight (Fig. $6 D$; Table 2) and spleen weight (Fig. 6E; Table 2) were also similar between IgM-KO and WT mice at two weeks after injury.

\section{Discussion}

This study shows that deficiency of IgM immunoglobulin results in impaired recovery following cervical $\mathrm{SCl}$ in mice. Overall, IgM-KO mice exhibited worse neurobehavioral recovery, coupled with increased lesion size, less white matter sparing, and enhanced deposition of complement-fixing IgG antibodies in the spinal cord as compared with their WT counterparts. These data provide evidence for the necessary role of lgM immunoglobulin in spontaneous recovery during cervical $\mathrm{SCl}$ and warrant further research into the therapeutic effect of $\operatorname{lgM}$ administration after $\mathrm{SCl}$. A recent clinical trial showing significant benefits of IgM-enriched immunoglobulin preparation for patients with pneumonia and lower levels of endogenous IgM (Brunner et al., 2013; Cavazzuti et al., 2014; Wand et al., 2016; Welte et al., 2018; Kalvelage et al., 2019; Willuweit et al., 2019) further supports this notion.

Using a rat model of cervical $\mathrm{SCl}$, we previously found early extravasation of IgM immunoglobulin in the lesioned spinal cord and a chronic expansion of splenic IgM 

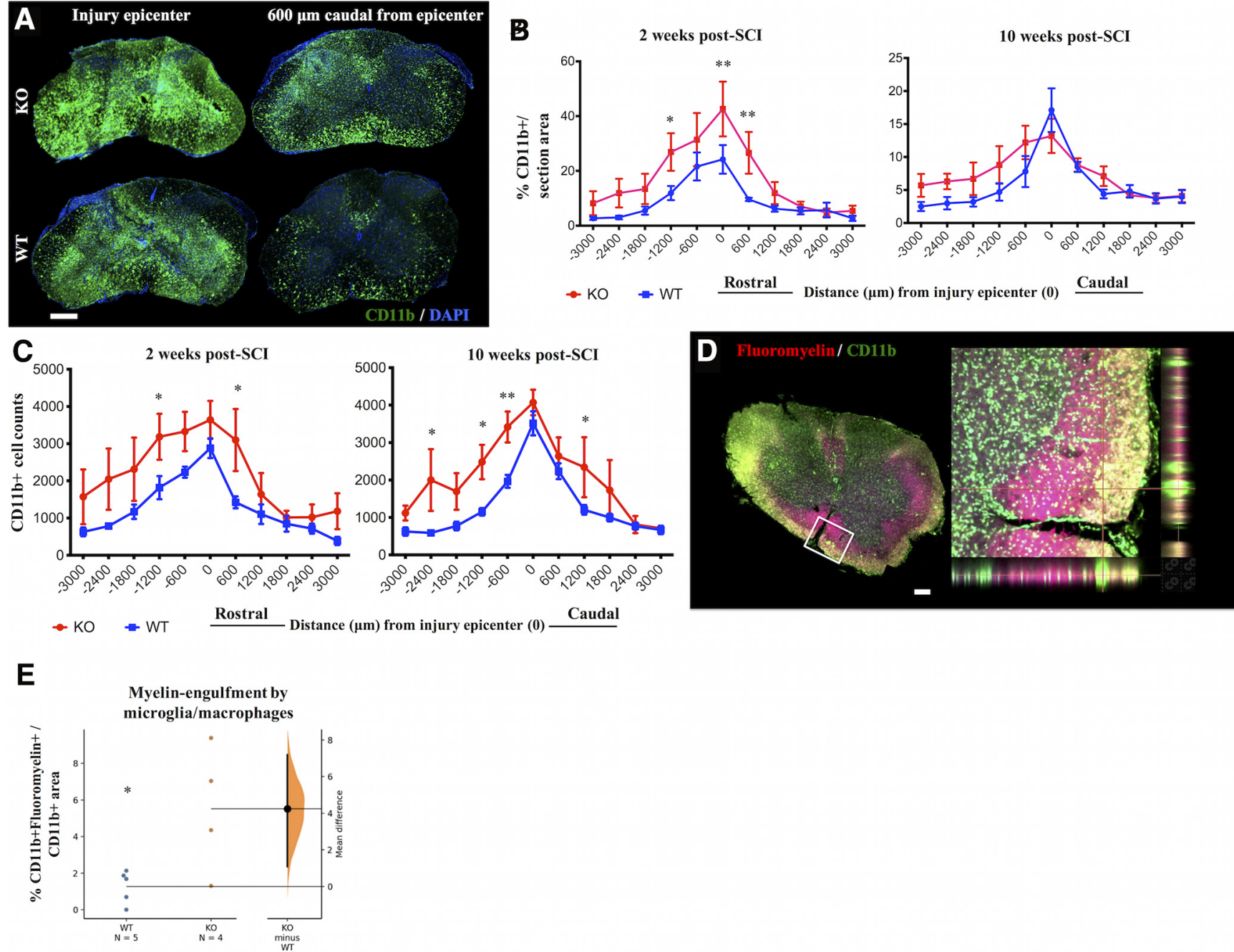

Figure 3. IgM-KO mice have more microglia/macrophages than WT controls. $\boldsymbol{A}$, Representative spinal cord sections stained for the microglia/macrophage markers CD11b and DAPI at two weeks post-SCI. Quantification of \% CD11b+ immunostained areas/total area $(\boldsymbol{B})$ and $\mathrm{CD} 11 \mathrm{~b}+$ cell counts $(\boldsymbol{C})$ rostro-caudally from the injury epicenter, at 2 and 10 weeks of injury. $\boldsymbol{D}$, Representative spinal cord section stained for myelin (fluoromyelin) and microglia/macrophages (CD11b) at two weeks post-SCl. Inset indicates area of co-localized CD11b and fluoromyelin signal. Myelin-engulfing macrophages appear yellow because of colocalization of green $(C D 11 b+$ signal) and red (fluoromyelin) signals in the single layer confocal image. $\boldsymbol{E}$, Gardner-Altman estimation plot showing quantification of \% area of co-localized CD11b+ and fluoromyelin + signal/total section area. Each dot indicates mean as averaged from 3 sections/animal, where sections were taken at distances $-1200,-600$, and $+600 \mu \mathrm{m}$ from the injury epicenter. Scale bar: $100 \mu \mathrm{m}$, $N=4-5$ animals/group $(\boldsymbol{B}, \boldsymbol{E}), 5$ animals/group $(\boldsymbol{C})$. Error bars indicate SEM; ${ }^{\star} p<0.05,{ }^{\star *} p<0.01$. See Table 1 for detailed statistical results in $\boldsymbol{B}, \boldsymbol{C}$ and Table 2 for statistical results in $\boldsymbol{E}$.

plasma cells (Ulndreaj et al., 2017). Additionally, we have observed chronically increased levels of serum IgM immunoglobulin in rats after cervical SCl (Ulndreaj et al., 2020). Circulating IgM immunoglobulin comprises the majority of naturally occurring antibodies. By binding a broad range of self and non-self-targets, naturally occurring antibodies constitute a rapid innate response to altered self-antigens and invading pathogens, thereby maintaining homeostasis against autoimmunity, infectious and other diseases (Ehrenstein and Notley, 2010). Thus, we hypothesized that the enhanced IgM response we observed in our rat $\mathrm{SCI}$ model could be protective. To test this hypothesis we induced $\mathrm{C} 6 / \mathrm{C} 7 \mathrm{SCl}$ in mice that lack secretory IgM immunoglobulin (Boes et al., 1998b) and compared their outcomes to WT littermate controls. These IgM-KO mice have undetectable serum IgM, although they express membrane IgM and all other secretory immunoglobulin classes (Boes et al., 1998b).

IgM-KO mice had significant deficits in coordination and other gait parameters in their hindlimbs compared with their WT counterparts during the chronic time points of our study (8-10 weeks post-SCl). When compared with shams, mice with SCl showed overall impairment in coordination, swing speed and print area in both fore- and hindlimbs, thus confirming the impairments previously observed in our $\mathrm{C6} / \mathrm{C} 7 \mathrm{SCl}$ mouse model (Forgione et al., 2017). When comparing IgM-KO to WT mice with $\mathrm{SCl}, \mathrm{KO}$ mice had greater impairments in coordination, lowered 
A

Injury epicenter
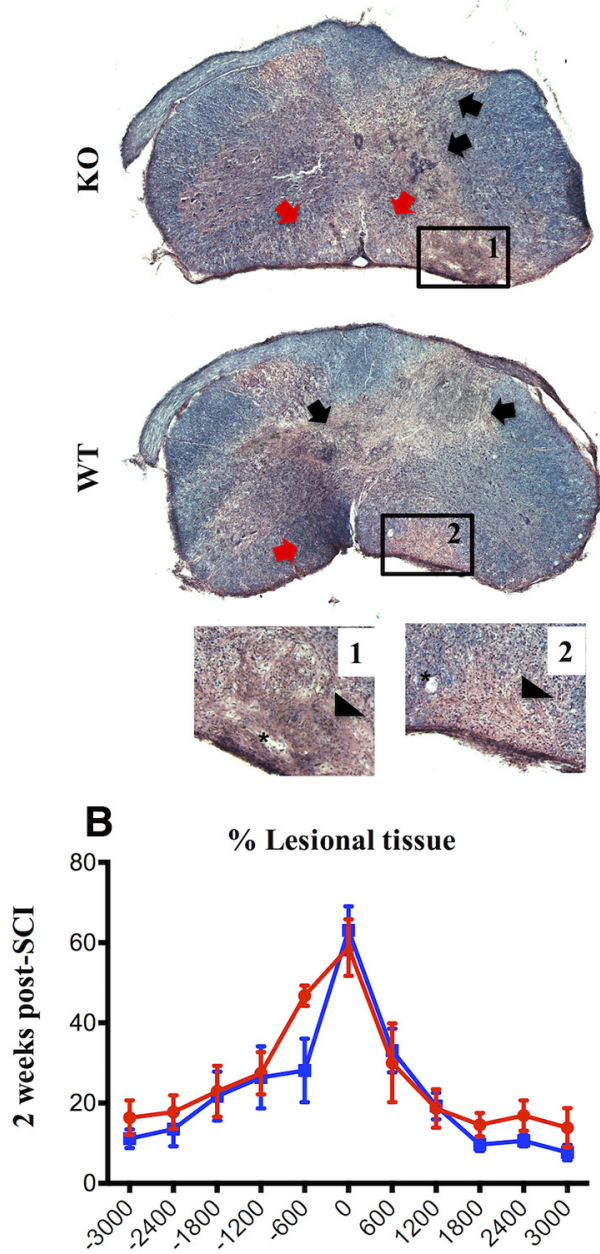

E

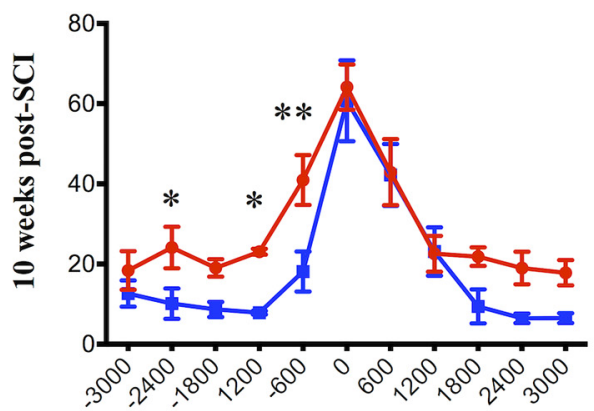

$600 \mu \mathrm{m}$ rostral from injury epicenter
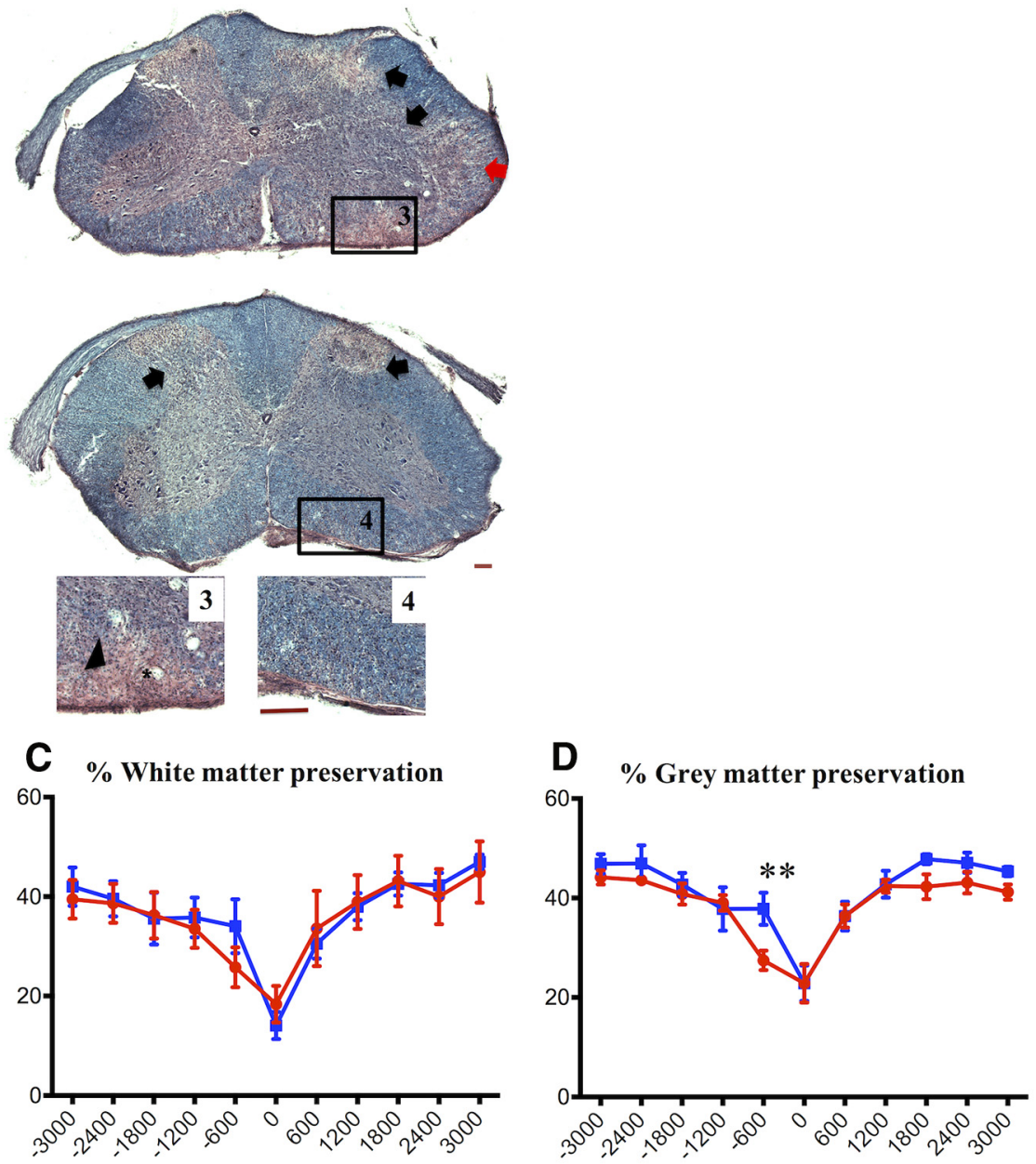

$\mathbf{F}$

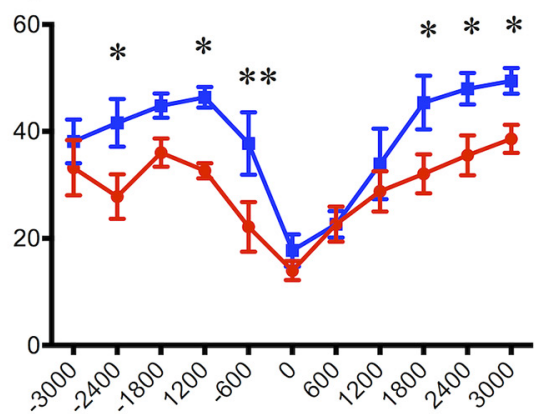

G

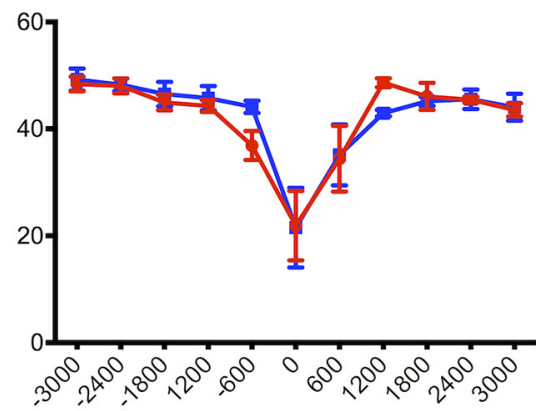

\footnotetext{
$\rightarrow K O=W T \stackrel{\text { Rostral }}{-}$ Distance $(\mu \mathrm{m})$ from injury epicenter (0) Caudal
}

Figure 4. IgM KO mice have more lesional tissue at 10 weeks post-SCI. $\boldsymbol{A}$, Representative HE and LFB images of spinal cord crosssections taken from an injured IgM-KO and WT mouse at the injury epicenter and $600 \mu \mathrm{m}$ rostral from the injury epicenter at 10 weeks post-SCI. Insets 1-4 indicate most severe lesional tissue. Black arrows indicate gray matter lesions and red arrows indicate white matter lesions. Asterisks indicate vacuoles. Scale bar: $100 \mu \mathrm{m}$. B-G, Quantification of lesional tissue and white/gray matter preservation by the Cavalieri method at 2 and 10 weeks post-SCI rostro-caudally from the injury epicenter. $\boldsymbol{B}-\boldsymbol{D}$, Lesional tissue and white and gray matter preservation in IgM-KO and WT mice at two weeks of injury. $E-G$, Lesional tissue and white and gray matter preservation at 10 weeks of injury $N=4-5$ /group; mean $\pm \mathrm{SEM}$; ${ }^{*} p<0.05,{ }^{* *} p<0.01$. 
A

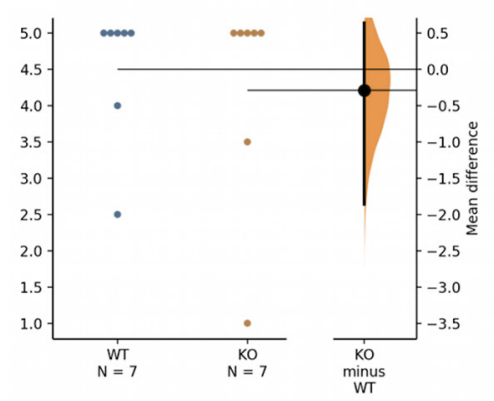

Grip strength

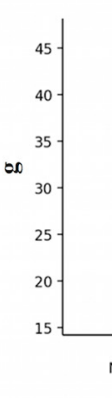

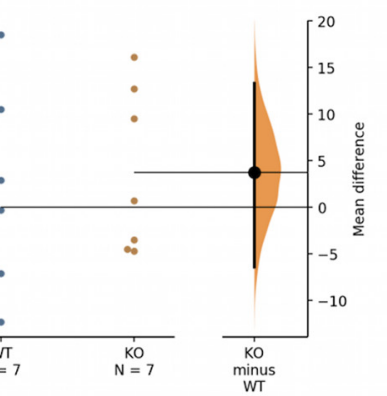

B

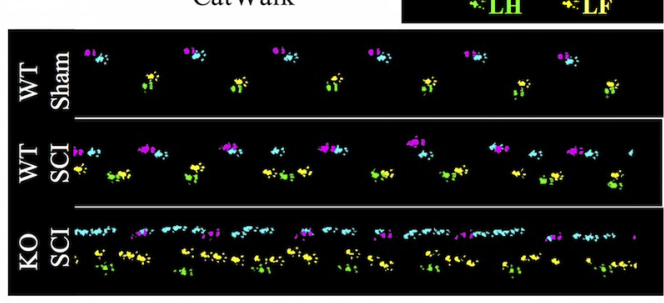

C Step sequence regularity

D Swing speed hindlimbs

E

Swing speed forelimbs

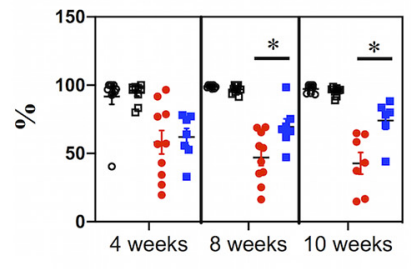

F Print area hindlimbs

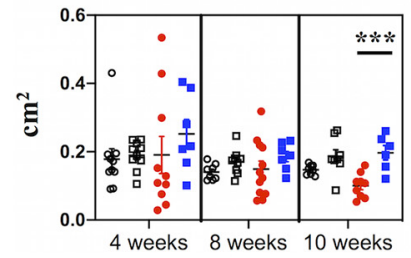

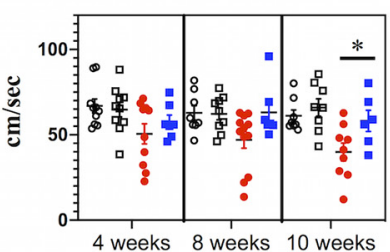

G

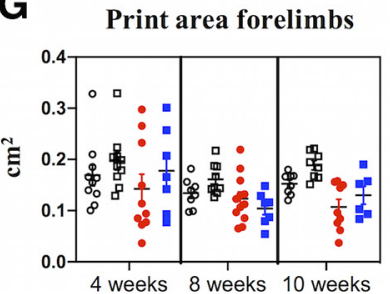

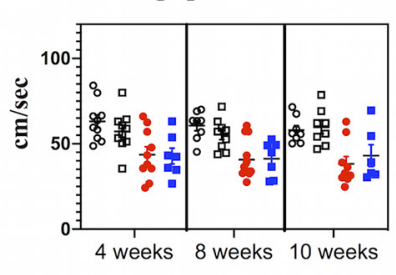

H Average body speed

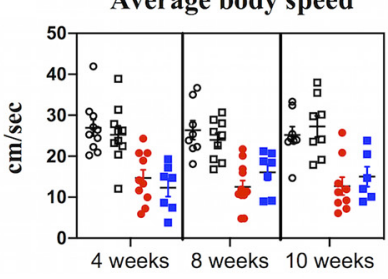

Groups

- KO Sham

口WT Sham

- $\mathrm{KO}$ SCI

- WT SCI

Figure 5. IgM deficiency results in impaired coordination during the chronic phase of SCl. $\boldsymbol{A}$, Gardner-Altman estimation plots of BMS and grip strength scores at two weeks after injury. See Table 2 for statistics details. $\boldsymbol{B}$, Representative images of locomotion in a sham WT animal as well as a WT and $\mathrm{KO}$ mouse with $\mathrm{SCl}$ at 10 weeks after injury, as recorded with CatWalk. $\boldsymbol{C}$, IgM-KO mice with SCl show deteriorated coordination compared with injured WT mice, as indicated by smaller step sequence regularity indices at 8 and 10 weeks after injury. See Table 2 for statistics details between WT and KO mice. $\boldsymbol{D}$, Hindlimb swing speed is slower in IgM-KO mice with SCI compared with their WT counterparts at 10 weeks of injury (Table 2). $\boldsymbol{E}$, There is no difference between WT and $\mathrm{KO}$ mice with $\mathrm{SCl}$ in forelimb swing speed (Table 2). $\boldsymbol{F}$, Hindlimb print area is significantly smaller in $\mathrm{KO}$ mice with $\mathrm{SCl}$, compared with their WT counterparts (Table 2). $\boldsymbol{G}$, Forelimb print areas are similar between IgM-KO and WT mice with SCl (Table 2). $\boldsymbol{H}$, Average body speed is similar between IgM-KO and WT mice with SCl (Table 2). Group size: $N=6-12$ mice/group. Mean \pm SEM, ${ }^{*} p<0.05,{ }^{* *} p<0.001$. Only significant differences between WT SCI and KO SCl groups are indicated with * on the graph, based on results shown in Table 2. For details on statistical analyses considering the effect of genotype, time after injury, and injury status on parameters shown in $\mathbf{C}-\boldsymbol{H}$, see Table 1.

swing speed and smaller print area in the hindlimbs. Importantly, both groups had similar average body speeds, suggesting that the above differences did not result from the confounding effect of body speed (Batka et al., 2014).

In line with these chronic neurologic impairments, we found increased lesion size and less white matter sparing in IgM-KO mice compared with WT mice at our last chronic time point of the study (10 weeks after injury). Interestingly, both groups had similar neurobehavioral and histologic outcomes at two weeks of injury. This suggested that IgM deficiency may affect pathomechanisms that are initiated during or after the two-week time point, which marks the beginning of the subacute phase in rodent SCl.

One relevant mechanism explored here is the expansion of $T$ cells and microglia/macrophages in the injured spinal cord. CD3 and CD11b cell expansion was assessed by quantifying the percent positive immunofluorescent area and by cell counts in spinal cord sections across a selected rostro-caudal axis from the injury epicenter. Of note, while microglia/macrophage responses are considered to peak by two weeks post-SCl in mice, this time point marks only the onset of T-cell infiltration in the lesioned spinal cord (Sroga et al., 2003). Also, in patients with SCI T-cell infiltrates are limited in the spinal cord and do not appear until weeks to months after trauma (Fleming et al., 2006). Given the decline in T-cell signal at 10 weeks, it is possible that here we have missed the peak of T-cell infiltration in the spinal cord. Despite this limitation regarding the optimal time point for the detection of CD3, our data show that compared with WT mice, IgM-KO mice had increased \% $\mathrm{CD} 3+$ and \% CD11b+ immunofluorescence area at two weeks post-SCl. At 10 weeks post-SCI, both groups had similar CD3 and CD11b + immunofluorescence areas. Interestingly, CD3 and CD11b cell counts were significantly higher in IgM-KO mice at both 2 and 10 weeks post-SCl. Our finding of higher CD3 and CD11b cell 
A Signs of pneumonia
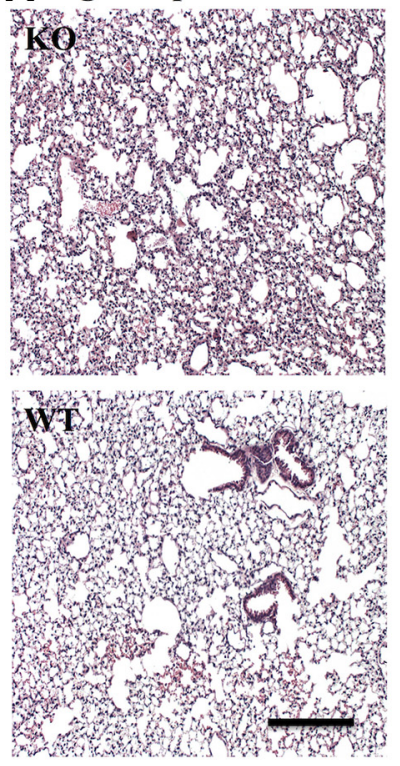

B

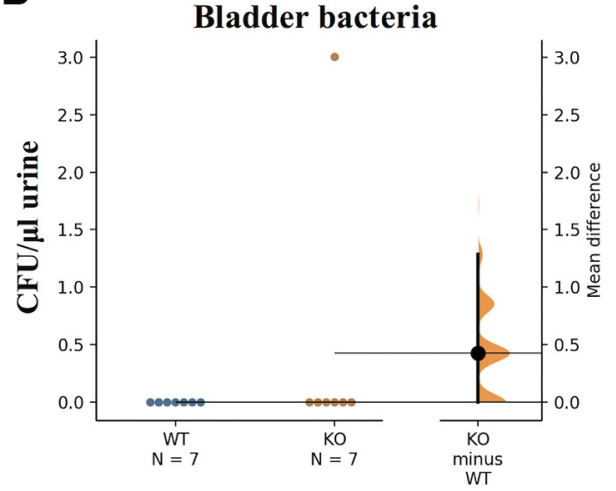

D

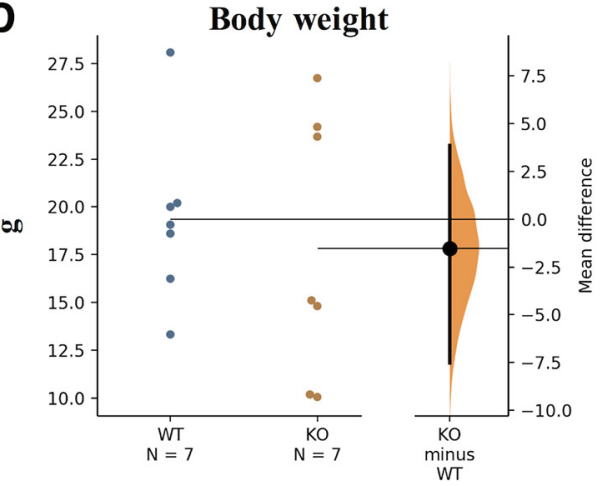

C

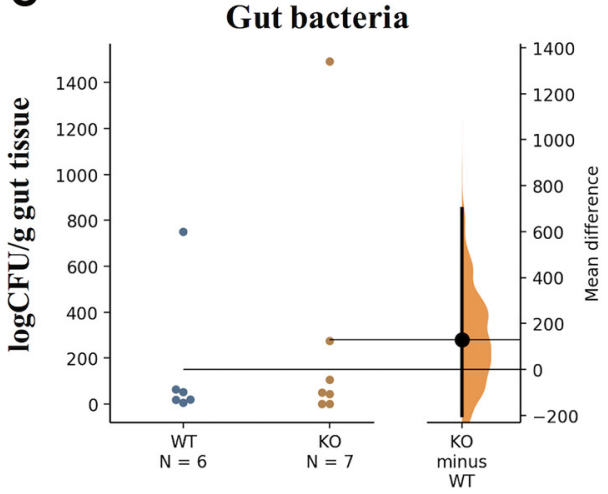

E

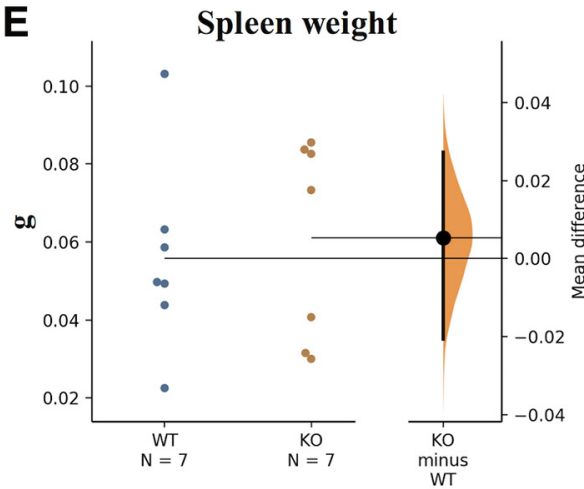

Figure 6. There is no evidence of bladder infection or pneumonia in IgM-KO mice or WT controls at two weeks of SCI. $\boldsymbol{A}$, HEstained lungs at $4 \times$ magnification indicating absence of inflammation. B, C, Gardner-Altman estimation plots of bladder-bacterial and gut-bacterial load in IgM-KO and WT mice at two weeks of SCl. Gardner-Altman estimation plots of body weight (D) and spleen weight $(\boldsymbol{E})$ in IgM-KO and WT mice at two weeks post-SCI. CFU = colony forming units; NS = nonsignificant. See Table 2 for detailed statistical results.

counts in IgM-KO mice with similar total immunofluorescence areas as WT mice at 10 weeks suggests that these cells in IgM-KO mice are on average smaller than in WT mice. This in turn can indirectly provide some information on the activation status of such cells or their subtype. For example, while both microglia and bloodderived macrophages are $C D 11 b+$, microglia tend to have a larger surface than blood-derived macrophages (Servet-Delprat et al., 2002). Similarly, IgM KO and WT mice may have different composition of CD3 cell subpopulations (CD4, CD8) with varying cell sizes depending on their activation state ( $\mathrm{Li}$ and Kurlander, 2010). Taken together, these data show that CD3 and CD11b cells are expanded in the spinal cord of IgM-KO mice compared with their WT counterparts and further suggest that the composition of these cells is likely different between IgM-KO and WT mice.

Moreover, we found that IgM-KO mice had increased IgG antibody deposition in the lesioned spinal cord at two weeks of injury. We and others have previously observed extensive widespread $\lg G$ in the lesioned parenchyma in SCl models (Ankeny et al., 2009; Ulndreaj et al., 2017; Zhou et al., 2019). Such antibodies are localized with neurons (Ulndreaj et al., 2017), bind to astrocytes or astrocytic markers (Ulndreaj et al., 2017; Arevalo-Martin et al., 2018; Hergenroeder et al., 2018) or to vascular endothelial cells within the injured spinal cord parenchyma (Zhou et al., 2019). The deposited antibodies can be autoreactive [e.g., IgGs bind to spinal cord components through their $F$ $\left(a b^{\prime}\right)_{2}$ portion] or not (e.g., IgGs bind to spinal cord cells through their Fc portion), and can persist throughout the disease course (Ankeny et al., 2009) or peak only during the subacute phase of SCI (Ulndreaj et al., 2017; Zhou et al., 2019). Regardless, there is strong evidence that IgG deposition in the spinal cord is detrimental to recovery after SCl (Ankeny et al., 2009; Zhou et al., 2019). Of note, circulating levels of IgG were similar between IgM-KO and WT mice at all time points of the study. This suggests that increased parenchymal IgG deposition at two weeks post-SCl in IgM-KO mice is likely not because of higher circulating IgG immunoglobulin. Rather, factors that affect $\lg$ extravasation in the tissue [such as blood-spinal cord barrier (BSCB) disruption] and or/turnover are likely to contribute to enhanced IgG deposition in IgM-KO mice at two weeks post-SCl. The potential effect of IgM on BSCB integrity was outside the scope of this study. However, the accumulation of IgG, which appeared largely in areas mostly affected by the physical impact of clip compression (i.e., injury epicenter, anterior and lateral white matter), suggests that the degree of BSCB disruption may be different between IgM-KO and WT mice. 
Here, we do not present direct evidence for the binding specificity of the $\lg G$ that was detected in the spinal cord. However, in our previous study we showed that circulating antibodies from rats with cervical $\mathrm{SCl}$ bind more strongly to cultured astrocytes (a cell type we found was IgG positive in injured spinal cords) than antibodies from uninjured rats. We also found that the spleen mounts a stronger antibody response against spinal cord antigens after injury. Furthermore, we performed competition assays to show that the signal we detect on the spinal cord is specific (Ulndreaj et al., 2017). These indirect lines of evidence suggest that some of the serum antibodies in mice with $\mathrm{SCl}$ are specific to spinal cord antigens. Others have also shown that $\mathrm{SCl}$ results in the induction of self-reacting antibodies (Ankeny et al., 2006, 2009). It should be noted that these induced antibodies comprise the minority of circulating antibodies (in the range of $\mu \mathrm{g} / \mathrm{ml}$ ) and we do not think that the signal we see in the spinal cord results exclusively from induced antibodies. Rather, given the large signal detected, we think it represents binding of naturally occurring antibodies that comprise the majority of the antibody pool in the body (in the $\mathrm{mg} / \mathrm{ml}$ range), and typically bind to self-antigens with low affinity (Lutz, 2007). Such antibodies are elevated following SCl (Arevalo-Martin et al., 2018). Moreover, it has been shown that in the absence of circulating $\mathrm{IgM}$ immunoglobulins, there are more self-reacting IgG antibodies (Boes et al., 2000). Taken together, we think the deposition of IgGs in the injured spinal cord in the present study results from at least three non-mutually exclusive phenomena: (1) the BSCB disruption which allows for serum IgGs to enter the parenchyma non-specifically; (2) the binding of naturally occurring antibodies to spinal cord self-antigens with low affinity; (3) the generation of immune auto-IgGs following $\mathrm{SCl}$ and potential exacerbation of this response because of the absence of secretory IgM (Boes et al., 2000) specifically.

The histology and inflammation data taken together indicate that enhanced neuroinflammation (rather than worse lesion) during the subacute phase (two weeks post$\mathrm{SCl}$ ) is linked to chronic neurobehavioral impairments in IgM-KO mice. This observation is in line with multiple studies linking early neuroinflammation to deteriorated histologic and locomotor outcomes in the chronic phase (Bao et al., 2011; Nguyen et al., 2012; Brennan et al., 2015). It is unclear why IgM-KO and WT mice have similar lesion size at two weeks despite significant differences in neuroinflammation at the same time point. However, a plausible explanation could be that the enhanced inflammation we observed in IgM-KO mice has long-term functional effects that have not been established by two weeks after injury. These effects could be related to processes including regeneration and plasticity (Ballermann and Fouad, 2006; Courtine et al., 2008; Rossignol and Frigon, 2011), and a favorable balance of remyelination/ demyelination (Hesp et al., 2015). Such mechanisms, although initiated early on during $\mathrm{SCl}$, take longer to establish and to give rise to quantifiable differences in neurobehavioral outcomes.
One of the mechanisms by which deposited IgGs have been shown to negatively impact outcomes after $\mathrm{SCl}$ is through activation of the complement system (Ankeny et al., 2009). In turn, complement activation enhances immune cell infiltration/activation (such as microglia/ macrophages and T-lymphocytes; Ankeny et al., 2009; Brennan et al., 2015) and promotes degradation of spared tissue by phagocytosis (Ankeny et al., 2009) or by direct complement-mediated attack (Qiao et al., 2010). Here, we examined whether increased IgG deposition in IgM-KO mice led to enhanced complement fixation in the lesioned spinal cord. In line with this hypothesis, we found enhanced C3b-IgG co-localization in the spinal cord of IgM-KO mice, as compared with their WT counterparts. Interestingly, C3b opsonizes antigens that are further taken up and engulfed by phagocytic cells (such as microglia and macrophages) through the interaction of $\mathrm{C} 3 \mathrm{~b}$ and complement receptor 3 (CR3), consisting of CD11b and CD18 (Ricklin et al., 2010). In an effort to understand the source of increased myelin loss in IgM-KO mice with $\mathrm{SCl}$, and given the widespread presence of CD11b + cells (typically microglia/macrophages) at two weeks of injury in $\mathrm{KO}$ mice, we further hypothesized that myelin was engulfed by $\mathrm{CD} 11 \mathrm{~b}+$ microglia/macrophages in IgM-KO mice. Indeed, by quantifying the CD11b+/fluoromyelin + area in sections with maximum IgG deposition (shown to have increased C3b deposition), we found that IgM-KO mice had significantly more myelin-engulfing microglia/macrophages than their WT counterparts. Taken together, this line of evidence indicates that the absence of secretory lgM immunoglobulin is associated with increased complement-fixing lgGs on the lesioned spinal cord, as well as the widespread presence of myelin-engulfing microglia/macrophages.

Research indicates that secretory IgM protects against detrimental IgG autoimmunity in multiple potentially overlapping pathways, which range from regulating the development of IgG autoantibodies to directly inhibiting their effector functions. For example, IgM antibodies enhance the phagocytic clearance of apoptotic cells and other cellular debris (Chen et al., 2009), which if left uncleared, could trigger pathogenic autoimmune responses (Henson, 2017). In addition, IgM regulates the development of pathogenic IgG autoantibody responses by controlling the generation of autoreactive $B$ cells throughout their life span. Such mechanisms include central tolerance to self-antigens early during $\mathrm{B}$ cell development (Nguyen et al., 2015), and later on the reduction of autoreactive BCR signaling (Tsiantoulas et al., 2017) and deletion/deactivation of self-reactive $B$ cells (Ouchida et al., 2012). Moreover, IgM immunoglobulin inhibits IgG autoantibody effector functions by binding directly to IgG's $\mathrm{F}(\mathrm{ab})_{2}$ component, thereby inhibiting IgG binding to selfantigens (Adib et al., 1990). We tested the latter possibility, given that in a previous study we found significant deposition of IgM antibodies in the spinal cord following $\mathrm{C} 7 \mathrm{SCl}$ in rats (Ulndreaj et al., 2017). However, contrary to our rat data, we did not find any significant lgM deposition at 2 or 10 weeks of injury in injured WT mice (data not shown), suggesting that IgM does not inhibit IgG binding in the injured spinal cord. 
Of note, IgM's protective effects on SCl recovery could be independent of IgG. For example, IgM was shown to induce proliferation of oligodendrocyte-precursor cells (OPCs) via Fc $\alpha / \mu \mathrm{R}$ signaling during brain development (Tanabe and Yamashita, 2018). Occurring within the first two weeks post-SCl, and primarily rostrally from the injury epicenter (Li and Leung, 2015), oligodendrogenesis is an endogenous regenerative process in rodent SCI (Zai and Wrathall, 2005; Lytle and Wrathall, 2007; Tripathi and McTigue, 2007; Lytle et al., 2009; Li and Leung, 2015) and has been a therapeutic target for multiple research groups aiming to reverse myelin loss after injury (Karimi-Abdolrezaee et al., 2006; Plemel et al., 2014; Papastefanaki and Matsas, 2015). Thus, future studies could investigate whether secretory IgM promotes endogenous OPC proliferation in SCl.

Importantly, circulating IgM is the carrier and regulator of AIM (also known as CD5L/Spalpha/API6; Hiramoto et al., 2018), a protein with debris clearance and macrophage survival function. In the absence of secretory IgM, circulating levels of AIM are undetectable and insufficient debris clearance was shown to lead to worsened disease progression in a model of acute kidney injury (Arai and Miyazaki, 2018). It is thus possible that worse outcomes observed in IgM-KO mice with $\mathrm{SCl}$ in the present study are because of insufficient AIM-mediated debris clearance. This possibility should be explored in future studies as AIM was shown to be a top gene upregulated by microglia/macrophages after SCI (Zhu et al., 2017), yet its role in $\mathrm{SCl}$ remains unknown.

In addition to the above positive effects, IgM protects against microbial infections. Here, we looked at a possible link between IgM deficiency and microbial infections after injury, as infections are linked with poor neurologic recovery in SCl (Failli et al., 2012; Brommer et al., 2016) and IgM-KO mice have been shown to be susceptible to microbial infections in past studies (Baumgarth et al., 2005). As UTIs and pneumonia are the most frequent infection types in patients with SCl (Garcia-Arguello et al., 2017), we looked at microbial loads in the bladder and signs of inflammation in the lungs at two weeks after injury. However, we found no signs of bladder infection or lung inflammation. Thus, our data suggest that the impaired recovery after $\mathrm{SCl}$ in the absence of secretory IgM immunoglobulin is not because of infections. However, it is important to note that our experiments were conducted in mice that were receiving antibiotics in their water and were infection free.

Although our data suggest that total IgM immunoglobulin may have a protective role in $\mathrm{SCl}$, it is important to note that not all IgM is beneficial for SCl. For example, some natural $\lg \mathrm{M}$ antibodies were shown to have significant detrimental effects on SCl outcomes by activating the immune system and further enhancing secondary injury (Narang et al., 2017). This duality of the lgM response during SCl reflects the overall complex role of the immune response in $\mathrm{SCl}$ pathophysiology, which has made the journey to discovering effective SCl therapies challenging. Delineating the role of critical pathophysiological factors in SCl recovery, such as important components of the immune system, will take us closer to developing effective treatments for this debilitating chronic condition, which given its complex nature, will ultimately necessitate the application of an array of treatment modalities (UIndreaj et al., 2016).

In conclusion, the present study shows that IgM immunoglobulin is important for recovery following cervical $\mathrm{SCl}$, as IgM deficiency resulted in impaired neurobehavioral and histologic outcomes, as well as increased $\lg G$ deposition, complement activation, T- cell infiltration and myelin-engulfing macrophages. We anticipate that future research will investigate whether circulating IgM levels are useful biomarkers of recovery in patients with $\mathrm{SCl}$, and ultimately, whether modulating IgM immunoglobulin levels can improve recovery.

\section{References}

Adib M, Ragimbeau J, Avrameas S, Ternynck T (1990) IgG autoantibody activity in normal mouse serum is controlled by $\operatorname{lgM}$. J Immunol 145:3807-3813.

Ankeny DP, Lucin KM, Sanders VM, McGaughy VM, Popovich PG (2006) Spinal cord injury triggers systemic autoimmunity: evidence for chronic B lymphocyte activation and lupus-like autoantibody synthesis. J Neurochem 99:1073-1087.

Ankeny DP, Guan Z, Popovich PG (2009) B cells produce pathogenic antibodies and impair recovery after spinal cord injury in mice. $J$ Clin Invest 119:2990-2999.

Arai S, Miyazaki T (2018) A scavenging system against internal pathogens promoted by the circulating protein apoptosis inhibitor of macrophage (AIM). Semin Immunopathol 40:567-575.

Arevalo-Martin A, Grassner L, Garcia-Ovejero D, Paniagua-Torija B, Barroso-Garcia G, Arandilla AG, Mach O, Turrero A, Vargas E, Alcobendas M, Rosell C, Alcaraz MA, Ceruelo S, Casado R, Talavera F, Palazón R, Sanchez-Blanco N, Maier D, Esclarin A, Molina-Holgado E (2018) Elevated autoantibodies in subacute human spinal cord injury are naturally occurring antibodies. Front Immunol 9:2365.

Ballermann M, Fouad K (2006) Spontaneous locomotor recovery in spinal cord injured rats is accompanied by anatomical plasticity of reticulospinal fibers. Eur J Neurosci 23:1988-1996.

Bao F, Fleming JC, Golshani R, Pearse DD, Kasabov L, Brown A, Weaver LC (2011) A selective phosphodiesterase-4 inhibitor reduces leukocyte infiltration, oxidative processes, and tissue damage after spinal cord injury. J Neurotrauma 28:1035-1049.

Basso DM, Fisher LC, Anderson AJ, Jakeman LB, McTigue DM, Popovich PG (2006) Basso mouse scale for locomotion detects differences in recovery after spinal cord injury in five common mouse strains. J Neurotrauma 23:635-659.

Batka RJ, Brown TJ, Mcmillan KP, Meadows RM, Jones KJ, Haulcomb MM (2014) The need for speed in rodent locomotion analyses. Anat Rec (Hoboken) 297:1839-1864.

Baumgarth N, Herman OC, Jager GC, Brown LE, Herzenberg LA, Chen J (2000) B-1 and B-2 cell-derived immunoglobulin M antibodies are nonredundant components of the protective response to influenza virus infection. J Exp Med 192:271-280.

Baumgarth N, Tung JW, Herzenberg LA (2005) Inherent specificities in natural antibodies: a key to immune defense against pathogen invasion. Springer Semin Immunopathol 26:347-362.

Boes M, Prodeus AP, Schmidt T, Carroll MC, Chen J (1998a) A critical role of natural immunoglobulin $\mathrm{M}$ in immediate defense against systemic bacterial infection. J Exp Med 188:2381-2386.

Boes M, Esau C, Fischer MB, Schmidt T, Carroll M, Chen J (1998b) Enhanced B-1 cell development, but impaired IgG antibody responses in mice deficient in secreted IgM. J Immunol 160:47764787. 
Boes M, Schmidt T, Linkemann K, Beaudette BC, MarshakRothstein A, Chen J (2000) Accelerated development of IgG autoantibodies and autoimmune disease in the absence of secreted IgM. Proc Natl Acad Sci USA 97:1184-1189.

Brennan FH, Gordon R, Lao HW, Biggins PJ, Taylor SM, Franklin RJM, Woodruff TM, Ruitenberg MJ (2015) The complement receptor C5aR controls acute inflammation and astrogliosis following spinal cord injury. J Neurosci 35:6517-6531.

Brommer B, Engel O, Kopp MA, Watzlawick R, Müller S, Prüss $\mathrm{H}$, Chen Y, DeVivo MJ, Finkenstaedt FW, Dirnagl U, Liebscher T, Meisel A, Schwab JM (2016) Spinal cord injury-induced immune deficiency syndrome enhances infection susceptibility dependent on lesion level. Brain 139:692-707.

Brunner R, Rinner W, Haberler C, Kitzberger R, Sycha T, Herkner H, Warszawska J, Madl C, Holzinger U (2013) Early treatment with IgM-enriched intravenous immunoglobulin does not mitigate critical illness polyneuropathy and/or myopathy in patients with multiple organ failure and SIRS/sepsis: a prospective, randomized, placebo-controlled, double-blinded trial. Crit Care 17:R213.

Cavazzuti I, Serafini G, Busani S, Rinaldi L, Biagioni E, Buoncristiano M, Girardis M (2014) Early therapy with IgM-enriched polyclonal immunoglobulin in patients with septic shock. Intensive Care Med 40:1888-1896.

Chen Y, Park YB, Patel E, Silverman GJ (2009) IgM antibodies to apoptosis-associated determinants recruit $\mathrm{C} 1 \mathrm{q}$ and enhance dendritic cell phagocytosis of apoptotic cells. J Immunol 182:60316043.

Courtine G, Song B, Roy RR, Zhong H, Herrmann JE, Ao Y, Qi J, Edgerton VR, Sofroniew MV (2008) Recovery of supraspinal control of stepping via indirect propriospinal relay connections after spinal cord injury. Nat Med 14:69-74.

Davies AL, Hayes KC, Dekaban GA (2007) Clinical correlates of elevated serum concentrations of cytokines and autoantibodies in patients with spinal cord injury. Arch Phys Med Rehabil 88:13841393.

DeVivo MJ, Krause JS, Lammertse DP (1999) Recent trends in mortality and causes of death among persons with spinal cord injury. Arch Phys Med Rehabil 80:1411-1419.

Donnelly DJ, Popovich PG (2008) Inflammation and its role in neuroprotection, axonal regeneration and functional recovery after spinal cord injury. Exp Neurol 209:378-388.

Ehrenstein MR, Notley CA (2010) The importance of natural IgM: scavenger, protector and regulator. Nat Rev Immunol 10:778-786.

Failli V, Kopp MA, Gericke C, Martus P, Klingbeil S, Brommer B, Laginha I, Chen Y, DeVivo MJ, Dirnagl U, Schwab JM (2012) Functional neurological recovery after spinal cord injury is impaired in patients with infections. Brain 135:3238-3250.

Fleming JC, Norenberg MD, Ramsay DA, Dekaban GA, Marcillo AE, Saenz AD, Pasquale-Styles M, Dietrich WD, Weaver LC (2006) The cellular inflammatory response in human spinal cords after injury. Brain 129:3249-3269.

Förger F, Matthias T, Oppermann M, Becker H, Helmke K (2004) Clinical significance of anti-dsDNA antibody isotypes: $\operatorname{lgG} / \mathrm{lgM}$ ratio of anti-dsDNA antibodies as a prognostic marker for lupus nephritis. Lupus 13:36-44.

Forgione N, Chamankhah M, Fehlings MG (2017) A mouse model of bilateral cervical contusion-compression spinal cord injury. J Neurotrauma 34:1227-1239.

Garcia-Arguello LY, O'Horo JC, Farrell A, Blakney R, Sohail MR, Evans CT, Safdar N (2017) Infections in the spinal cord-injured population: a systematic review. Spinal Cord 55:526-534.

Hayes KC, Hull TCL, Delaney GA, Potter PJ, Sequeira KAJ, Campbell K, Popovich PG (2002) Elevated serum titers of proinflammatory cytokines and CNS autoantibodies in patients with chronic spinal cord injury. J Neurotrauma 19:753-761.

Henson PM (2017) Cell removal: efferocytosis. Annu Rev Cell Dev Biol 33:127-144.

Hergenroeder GW, Redell JB, Choi HA, Schmitt L, Donovan W, Francisco GE, Schmitt K, Moore AN, Dash PK (2018) Increased levels of circulating glial fibrillary acidic protein and collapsin response mediator protein-2 autoantibodies in the acute stage of spinal cord injury predict the subsequent development of neuropathic pain. J Neurotrauma 35:2530-2539.

Hesp ZC, Goldstein EZ, Goldstein EA, Miranda CJ, Kaspar BK, Kaspar BK, McTigue DM (2015) Chronic oligodendrogenesis and remyelination after spinal cord injury in mice and rats. J Neurosci 35:1274-1290.

Hiramoto E, Tsutsumi A, Suzuki R, Matsuoka S, Arai S, Kikkawa M, Miyazaki T (2018) The IgM pentamer is an asymmetric pentagon with an open groove that binds the AIM protein. Sci Adv 4: eaau1199.

Ho J, Tumkaya T, Aryal S, Choi H, Claridge-Chang A (2019) Moving beyond $P$ values: data analysis with estimation graphics. Nat Methods 16:565-566.

Kalvelage C, Zacharowski K, Bauhofer A, Gockel U, Adamzik M, Nierhaus A, Kujath P, Eckmann C, Pletz MW, Bracht H, Simon TP, Winkler M, Kindgen-Milles D, Albertsmeier M, Weigand M, Ellger B, Ragaller M, Ullrich R, Marx G (2019) Personalized medicine with IgGAM compared with standard of care for treatment of peritonitis after infectious source control (the PEPPER trial): study protocol for a randomized controlled trial. Trials 20:156.

Karimi-Abdolrezaee S, Eftekharpour E, Wang J, Morshead CM, Fehlings MG (2006) Delayed transplantation of adult neural precursor cells promotes remyelination and functional neurological recovery after spinal cord injury. J Neurosci 26:3377-3389.

Kopp MA, Watzlawick R, Martus P, Failli V, Finkenstaedt FW, Chen Y, DeVivo MJ, Dirnagl U, Schwab JM (2017) Long-term functional outcome in patients with acquired infections after acute spinal cord injury. Neurology 88:892-900.

Li N, Leung GKK (2015) Oligodendrocyte precursor cells in spinal cord injury: a review and update. BioMed Res Int 2015:235195.

Li Y, Kurlander RJ (2010) Comparison of anti-CD3 and anti-CD28coated beads with soluble anti-CD3 for expanding human T cells: differing impact on CD8 T cell phenotype and responsiveness to restimulation. J Transl Med 8:104.

Lutz HU (2007) Homeostatic roles of naturally occurring antibodies: an overview. J Autoimmun 29:287-294.

Lytle JM, Wrathall JR (2007) Glial cell loss, proliferation and replacement in the contused murine spinal cord. Eur J Neurosci 25:17111724.

Lytle JM, Chittajallu R, Wrathall JR, Gallo V (2009) NG2 cell response in the CNP-EGFP mouse after contusive spinal cord injury. Glia 57:270-285.

Miyazaki T, Yamazaki T, Sugisawa R, Gershwin ME, Arai S (2018) AIM associated with the IgM pentamer: attackers on stand-by at aircraft carrier. Cell Mol Immunol 15:563-574.

Mizrachi Y, Ohry A, Aviel A, Rozin R, Brooks ME, Schwartz M (1983) Systemic humoral factors participating in the course of spinal cord injury. Paraplegia 21:287-293.

Narang A, Qiao F, Atkinson C, Zhu H, Yang X, Kulik L, Holers VM, Tomlinson S (2017) Natural IgM antibodies that bind neoepitopes exposed as a result of spinal cord injury, drive secondary injury by activating complement. J Neuroinflammation 14:120.

Nguyen DH, Cho N, Satkunendrarajah K, Austin JW, Wang J, Fehlings MG (2012) Immunoglobulin G (IgG) attenuates neuroinflammation and improves neurobehavioral recovery after cervical spinal cord injury. J Neuroinflammation 9:224.

Nguyen TTT, Elsner RA, Baumgarth N (2015) Natural IgM prevents autoimmunity by enforcing $\mathrm{B}$ cell central tolerance induction. $\mathrm{J}$ Immunol 194:1489-1502.

Ouchida R, Mori H, Hase K, Takatsu H, Kurosaki T, Tokuhisa T, Ohno $\mathrm{H}$, Wang JY (2012) Critical role of the IgM Fc receptor in IgM homeostasis, B-cell survival, and humoral immune responses. Proc Natl Acad Sci USA 109:E2699-E2706.

Papastefanaki F, Matsas R (2015) From demyelination to remyelination: the road toward therapies for spinal cord injury. Glia 63:11011125.

Petrova NV, Ponomaryova AM, Alyoshkin VA, Eliseyev AT, Yumashev GS (1993) Serum rheumatoid factors in spinal cord injury patients. Paraplegia 31:265-268. 
Plemel JR, Keough MB, Duncan GJ, Sparling JS, Yong VW, Stys PK, Tetzlaff W (2014) Remyelination after spinal cord injury: is it a target for repair? Prog Neurobiol 117:54-72.

Qiao F, Atkinson C, Kindy MS, Shunmugavel A, Morgan BP, Song H, Tomlinson S (2010) The alternative and terminal pathways of complement mediate post-traumatic spinal cord inflammation and injury. Am J Pathol 177:3061-3070.

Ricklin D, Hajishengallis G, Yang K, Lambris JD (2010) Complement: a key system for immune surveillance and homeostasis. Nat Immunol 11:785-797.

Rossignol S, Frigon A (2011) Recovery of locomotion after spinal cord injury: some facts and mechanisms. Annu Rev Neurosci 34:413-440.

Sanjurjo L, Amézaga N, Aran G, Naranjo-Gómez M, Arias L, Armengol C, Borràs FE, Sarrias M-R (2015) The human CD5L/AIMCD36 axis: a novel autophagy inducer in macrophages that modulates inflammatory responses. Autophagy 11:487-502.

Servet-Delprat C, Arnaud S, Jurdic P, Nataf S, Grasset MF, Soulas C, Domenget C, Destaing O, Rivollier A, Perret M, Dumontel C, Hanau D, Gilmore GL, Belin MF, Rabourdin-Combe C, Mouchiroud G (2002) Flt3+ macrophage precursors commit sequentially to osteoclasts, dendritic cells and microglia. BMC Immunol 3:15.

Sroga JM, Jones TB, Kigerl KA, McGaughy VM, Popovich PG (2003) Rats and mice exhibit distinct inflammatory reactions after spinal cord injury. J Comp Neurol 462:223-240.

Su J, Georgiades A, Wu R, Thulin T, de Faire U, Frostegård J (2006) Antibodies of IgM subclass to phosphorylcholine and oxidized LDL are protective factors for atherosclerosis in patients with hypertension. Atherosclerosis 188:160-166.

Tanabe S, Yamashita T (2018) B-1a lymphocytes promote oligodendrogenesis during brain development. Nat Neurosci 21:506-516.

Tripathi R, McTigue DM (2007) Prominent oligodendrocyte genesis along the border of spinal contusion lesions. Glia 55:698-711.

Tsiantoulas D, Kiss M, Bartolini-Gritti B, Bergthaler A, Mallat Z, Jumaa H, Binder CJ (2017) Secreted IgM deficiency leads to increased BCR signaling that results in abnormal splenic B cell development. Sci Rep 7:3540.

Ulndreaj A, Chio JCT, Ahuja CS, Fehlings MG (2016) Modulating the immune response in spinal cord injury. Expert Rev Neurother $16: 1127-1129$.
Ulndreaj A, Tzekou A, Mothe AJ, Siddiqui AM, Dragas R, Tator $\mathrm{CH}$, Torlakovic EE, Fehlings MG (2017) Characterization of the antibody response after cervical spinal cord injury. J Neurotrauma 34:1209-1226.

Ulndreaj A, Tzekou A, Siddiqui AM, Fehlings MG (2020) Effects of experimental cervical spinal cord injury on peripheral adaptive immunity. PLoS One 15:e0241285.

Vidal PM, Karadimas SK, Ulndreaj A, Laliberte AM, Tetreault L, Forner S, Wang J, Foltz WD, Fehlings MG (2017) Delayed decompression exacerbates ischemia-reperfusion injury in cervical compressive myelopathy. JCl Insight 2:e92512.

Wand S, Klages M, Kirbach C, Warszawska J, Meybohm P, Zacharowski K, Koch A (2016) IgM-enriched immunoglobulin attenuates systemic endotoxin activity in early severe sepsis: a before-after cohort study. PLoS One 11:e0160907.

Welte T, Dellinger RP, Ebelt H, Ferrer M, Opal SM, Singer M, Vincent JL, Werdan K, Martin-Loeches I, Almirall J, Artigas A, Ignacio Ayestarán J, Nuding S, Ferrer R, Sirgo Rodríguez G, Shankar-Hari M, Álvarez-Lerma F, Riessen R, Sirvent JM, Kluge S, et al. (2018) Efficacy and safety of trimodulin, a novel polyclonal antibody preparation, in patients with severe community-acquired pneumonia: a randomized, placebo-controlled, double-blind, multicenter, phase II trial (CIGMA study). Intensive Care Med 44:438-448.

Willuweit K, Bezinover D, Herzer K, Nowak KM, Paul A, Saner FH (2019) Efficacy of IgM-enriched immunoglobulin for vasopressor-resistant vasoplegic shock after liver transplantation. Transplantation 103:381-386.

Zai LJ, Wrathall JR (2005) Cell proliferation and replacement following contusive spinal cord injury. Glia 50:247-257.

Zajarías-Fainsod D, Carrillo-Ruiz J, Mestre H, Grijalva I, Madrazo I, Ibarra A (2012) Autoreactivity against myelin basic protein in patients with chronic paraplegia. Eur Spine J 21:964-970.

Zhou T, Zheng Y, Sun L, Badea SR, Jin Y, Liu Y, Rolfe AJ, Sun H, Wang $X$, Cheng Z, Huang Z, Zhao N, Sun X, Li J, Fan J, Lee C, Megraw TL, Wu W, Wang G, Ren Y (2019) Microvascular endothelial cells engulf myelin debris and promote macrophage recruitment and fibrosis after neural injury. Nat Neurosci 22:421-435.

Zhu Y, Lyapichev K, Lee DH, Motti D, Ferraro NM, Zhang Y, Yahn S, Soderblom C, Zha J, Bethea JR, Spiller KL, Lemmon VP, Lee JK (2017) Macrophage transcriptional profile identifies lipid catabolic pathways that can be therapeutically targeted after spinal cord injury. J Neurosci 37:2362-2376. 